\title{
ANALYSING THE RICE STRAW RECYCLING PROBLEMS IN BEHEIRA GOVERNORATE
}

\author{
HEBA ESSAM ELDEIN ALI SALAMA
}

Agricultural Extension \& Rural Development Res. Inst, ARC, Giza, Egypt

(Manuscript received 7 August 2018)

\begin{abstract}
$\mathrm{T}$ he study aimed at analysing rice straw recycling problems according to IQ Matrix, indentifying the officials \& executives' opinions and suggesting some extension activities based on the matrix results. A Random sample of 113 farmers was selected from three districts. Data were collected through focus group discussions and in-depth interviews during February and March 2018.
\end{abstract}

The study revealed the following results:

The problems of recycling rice straw started about 10 years ago. The most important aspects of these problems were high prices of the Compost \& Non-Traditional Fodder inputs, high prices of machines, small agricultural $\&$ animals holdings sizes. The most positives aspects of the problems related to rice straw recycling were modification of the behaviour of the respondents, reducing the chemical fertilizers' cost, and recognizing the advantages of N.T.F.

Farmer is the first affected one by the problems of recycling rice straw and the agricultural extension organization is the most important agency associated with these problems as well as agricultural cooperatives, Ministry of Environment and also private sector. The respondents have awareness of how the various organizations affect negatively or positively on the rice straw problems. Recently, both the agricultural extension workers and Ministry of Environment have significant role in the implementation of Compost \& N.T.F.

From the view points of officials and executive respondents a high attention should be paid to support the agricultural extension workers. Their most important suggestions were implementing extension activities regarding to rice straw recycling to raise the farmers' awareness according to the scientific principles.

The most important suggestions to solve the rice straw recycling problems were supporting the agricultural cooperative with some machines, encouraging small farmers to form aggregates and conducting specialized training programs for agricultural extension workers. 


\title{
تحليل مشكلات تدوير قش الأرز بمحافظة البحيرة
}

\author{
هبه عصام الاين علي سلامه \\ معرد بحوث الإرشاد الزراعي والنتمبة الريفية - مركز البحوث الزراعية - الجبزة- مصر
}

\begin{abstract}
المستخلص
\end{abstract}
استهدف البحث تحليل مشكلات تدوير قش الأرز بمحافظة البحيرة باستخدام مصفوفة

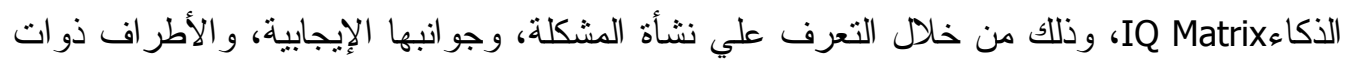

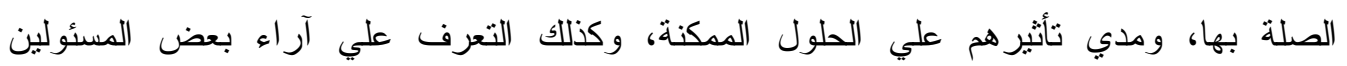

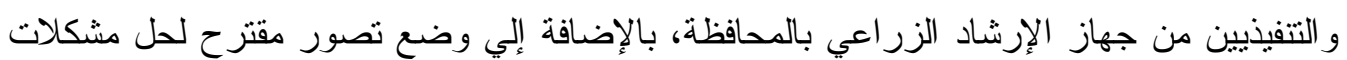
تدوير قش الأرز وفقاً للنموذج المستخدم، وأُجري البحث بثثلاث مراكز إدارية بمحافظة البحيرة، ونم استيفاء البيانات البحثية من مجمو عتين من الزراع المستهدفين بتدوير قش الأرز تم اختيار هم عشو ائياً

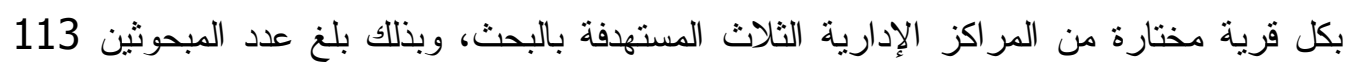

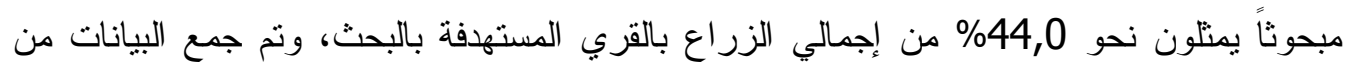
خلال المجموعات النقانشية مع الزر اع، وباستخدام المقابلات المتعمقة مع المسئولين و التنفيذيين خلال شهري فبر اير ومارس 2018، وتلخصت أهم نتائج البحث فيما يلي:

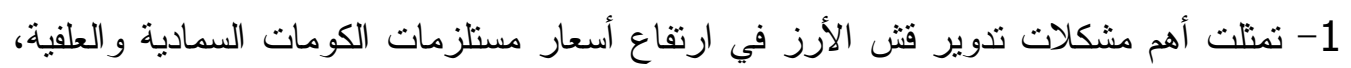

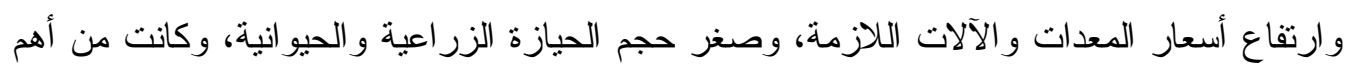

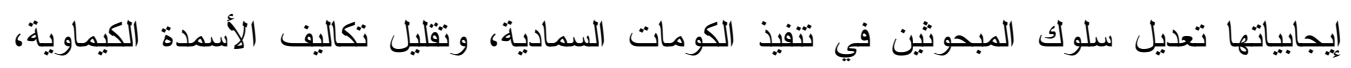

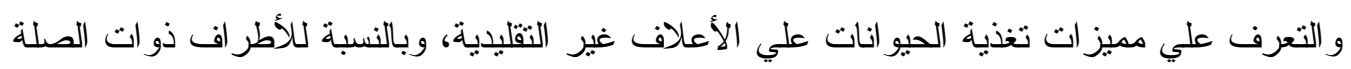
بمشكلات تدوير فش الأرز، أوضح البحث أن المزارع يعد المنضرر الأول من مشكلات تدوير قش فأش

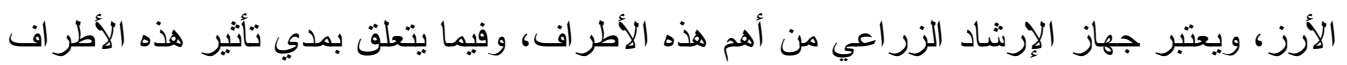

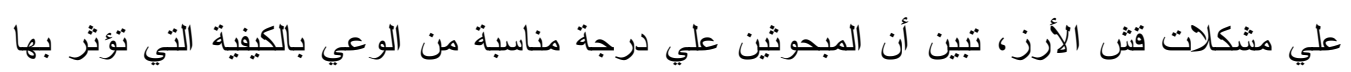

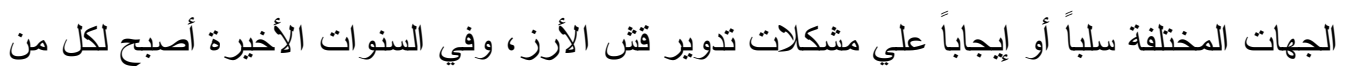
المرشدين الزر اعيين ووزارة البيئة دوراً ملحوظاً في تتفيذ الكومات السمادية و العلفية، كما أثنار

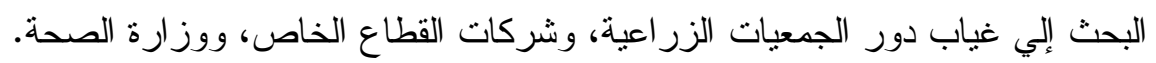

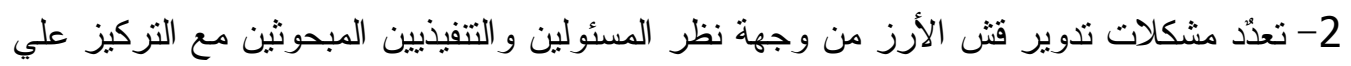

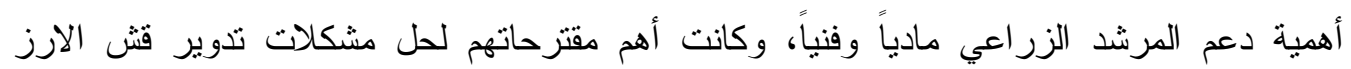

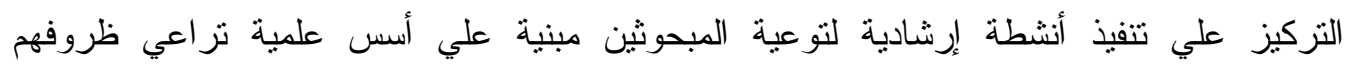

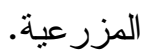


3- تمنلت أهم المقترحات لحل مشكلات تدوير فش الأرز في دعم الجمعيات التعاونية الزراعية

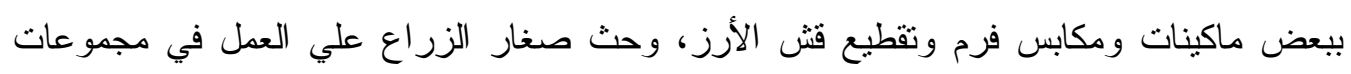

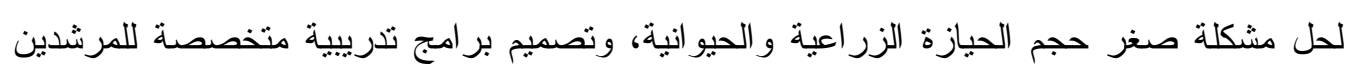
الزر اعيين.

\section{المقدمة و المشكلة البحثية}

تزايدت في السنوات الأخيرة قيمة المخلفات أو النفايات الزر اعية كأحد الموارد المربحة ولمة

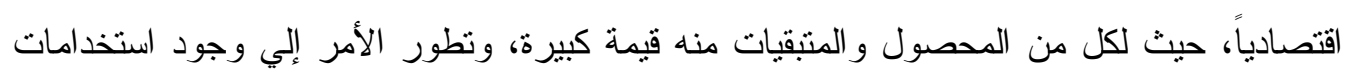

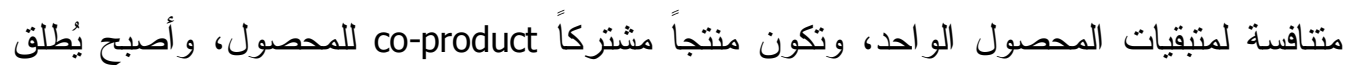
علي المخلفات الزر اعية مصطلح متبقيات المحاصيل الزر اعية، (10: ص 1 1).

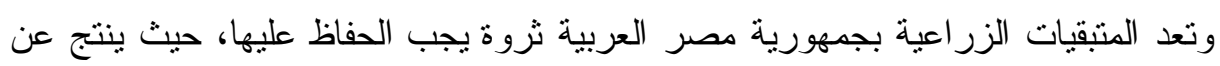

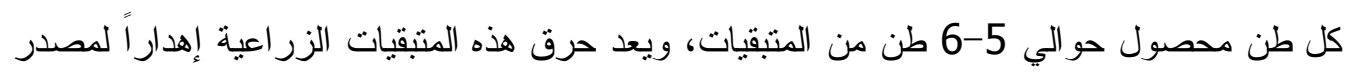

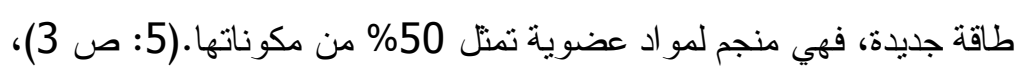

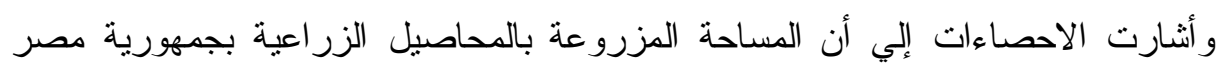
العربية تبلغ ثماني مليون وسبعمائة وثلاثة وثمانون ألف وخمسائة وسبعة عشر فدان ينتج عنها

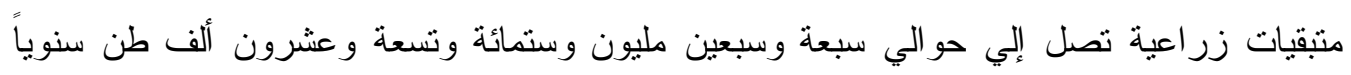

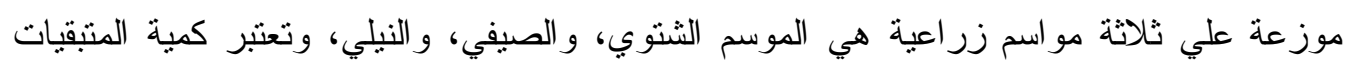

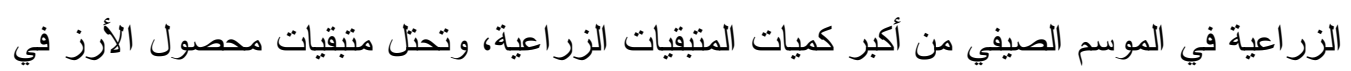

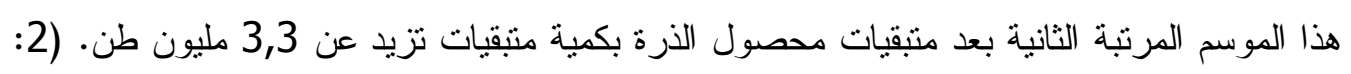

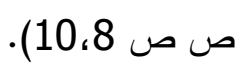

وكما تعتبر متبقيات محصول الأرز مشكلة بيئية كبيرة إذا أُسيئ استخدامها أو إذا طُبقت أساليب غير آمنة للتخلص منها، فهي أيضاً تعتبر ثروة كبيرة إذا أمكن استغلالها بطريقة صحيحة، لذا لذأ فإن مجال تدوير قش الأزر أصبح من المجالات التي توليها وزارة الزر اعة المصرية الهتماماً كبيراً خاصة في السنو ات الأخيرة.

حيث ينسبب حرق قش الأرز في كثثر من الأضرار وأصبح أحد المسبيات الرئيسية في

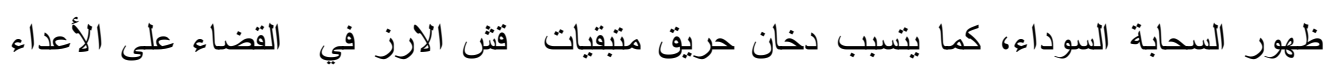

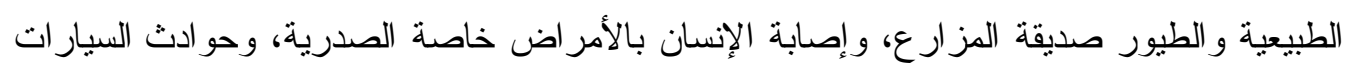

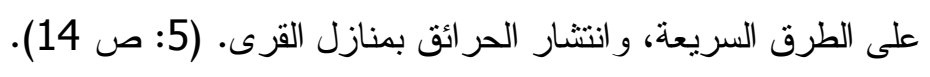

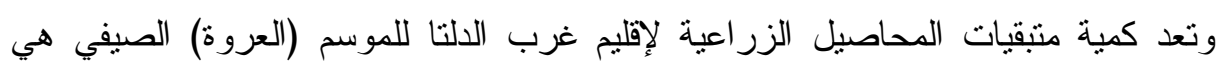

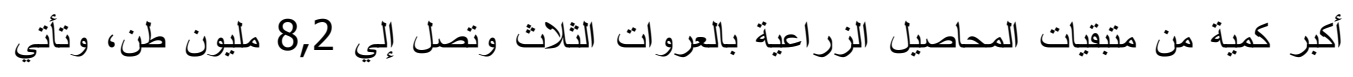
محافظة البحيرة كإحدي محافظات الإقليم في المركز الأول من حيث كمية متبقيات المحاصيل

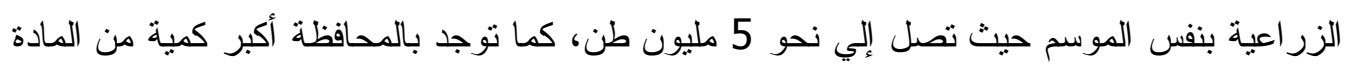

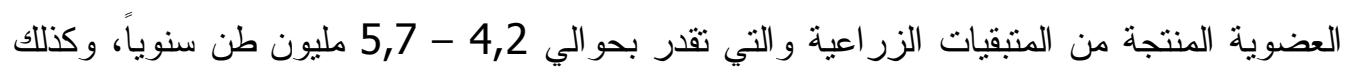

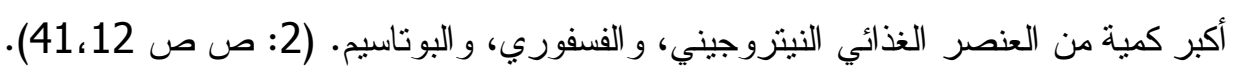


وتعتبر محافظة البحيرة من أكبر محافظات جمهورية مصر العربية من حيث المساحة

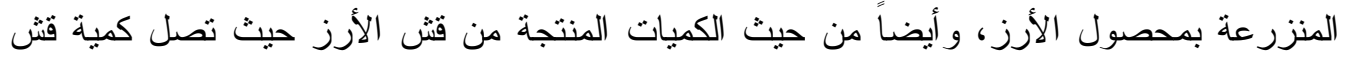

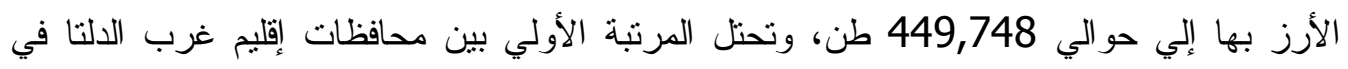

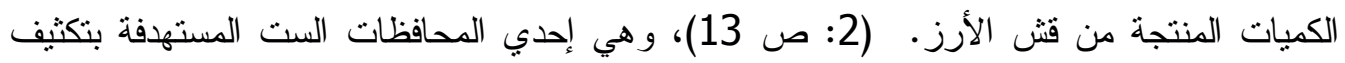

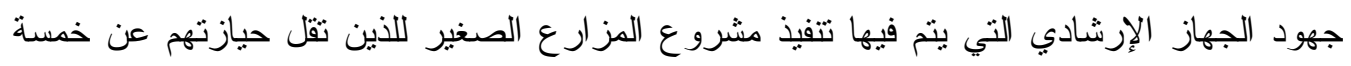

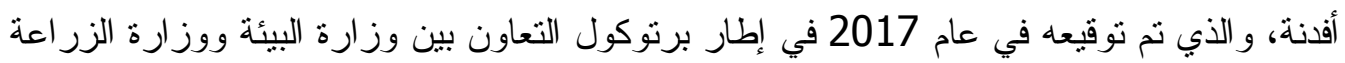

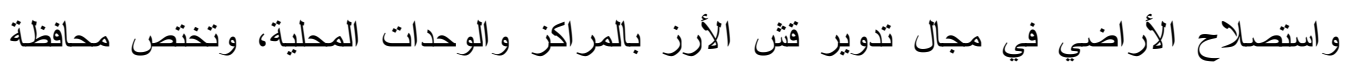

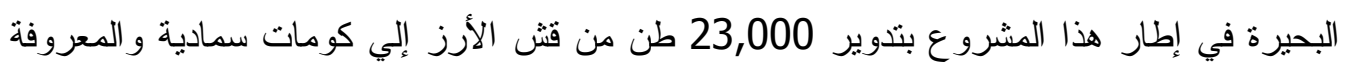
بسماد الكمبوست، و2000 طن من قش الأرز إلي أعلاف غبر تقليدية، وتتوزع الكمبات المستهدفة

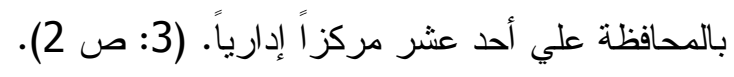
وتتعدد الدراسات التي أثنتت ارتفاع القيمة الاقتصادية لقش الأرز ، وادئ واستعداد الزراع لتنفيذ

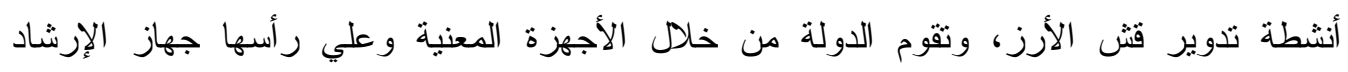
الزر اعي بكثير من الأنشطة الإرشادية التي تستهدف رفع و وعي المز ارعين بأهمية قش الأرز ، وطرق

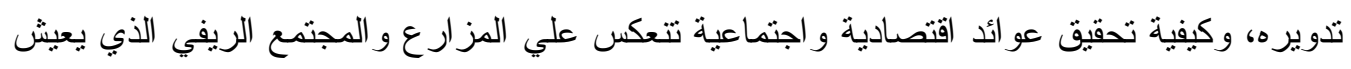

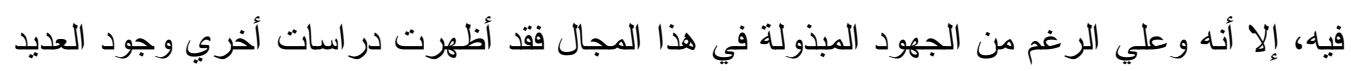
من المشكلات التي تو اجه الزراع في تدوير فش الأرز، بالإضافة إلي امتداد هذه المشكلات لفترة طويلة.

ومن المعلوم أن محافظة البحيرة تعد من المحافظات الرئيسية في زراعة محصول الأرز ،

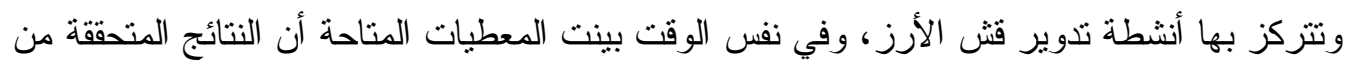

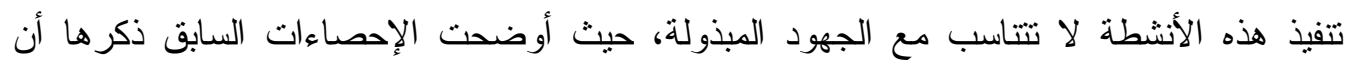
كميات كبيرة من قش الأرز تزيد عن 400 ألف طن لا يتم استيعابها ضمن أنشطة التدوير التي تتم بالمحافظة، وبذلك تعتبر كميات قش الأرز المستهدفة بالتدوير بمحافظة البحيرة قليلة بالمقارنة بكمية

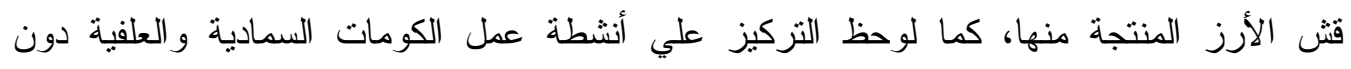

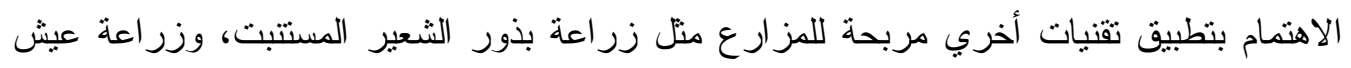

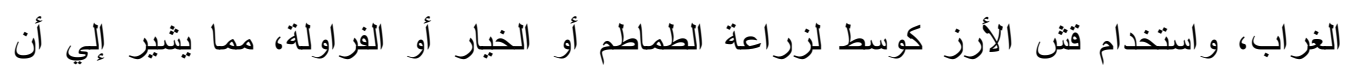

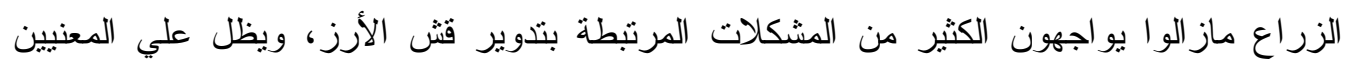

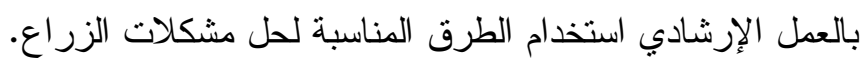

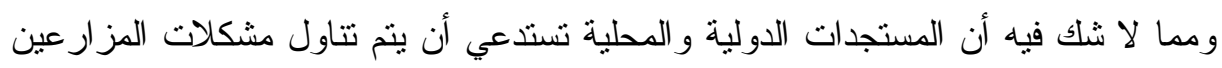

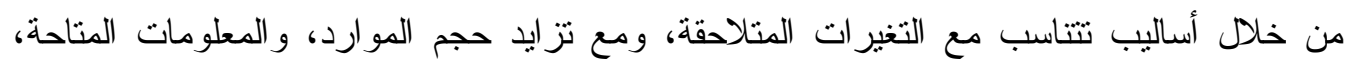

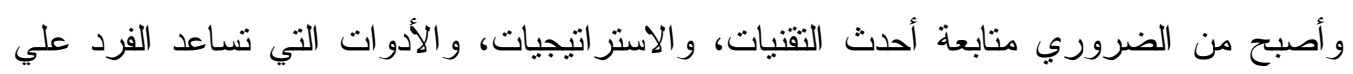
البقاء في الصدارة. وفي هذا السياق وما يتعلق بالأساليب الحديثة للتفكير الفعال في حل المشكلات فقد كان أثناء دراسته يبحث عن تفسير لاختلاف فصل الطلاب الأذكى عن فصول بافي بالافي 
الطلاب، و السبب ور اء حصول طلاب علي علامات در اسية أقل من أقر انهم، بالرغم من أنهم بذلو الفا نفس القدر من الجهر والوقت إن لم يكن أعلي، ولديهم القدر المطلوب من الاستعداد للتعلم، وتطوير

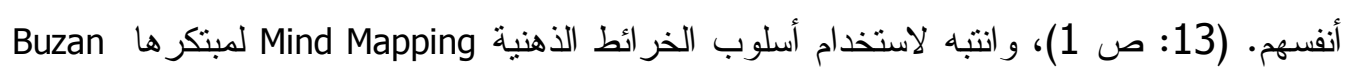

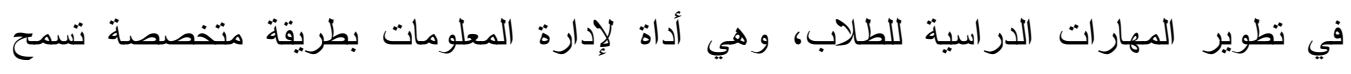
بتوظيف القدرات غير المحدودة للعقل البشري نحو التفكير المنطقي، وتنظور إلى أن تكون أداة إدارة

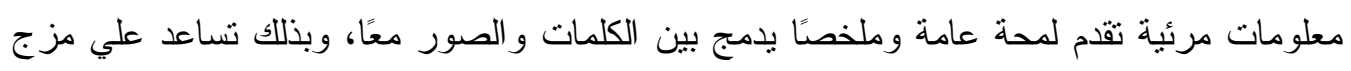

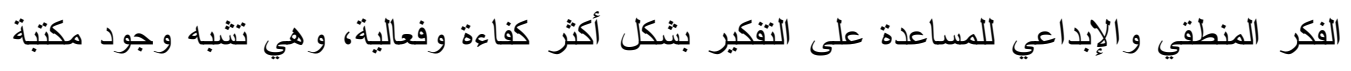

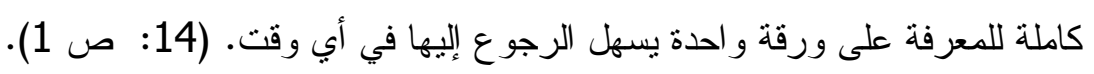
وفي دراسة Smith et.al (21: ص 1: 1) التي ركزت علي استخدام الخريطة الذهنية لتقييم

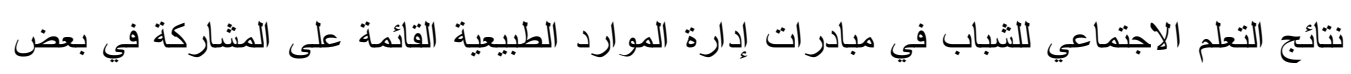

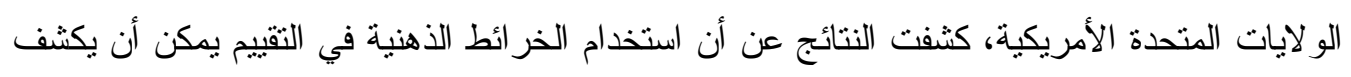

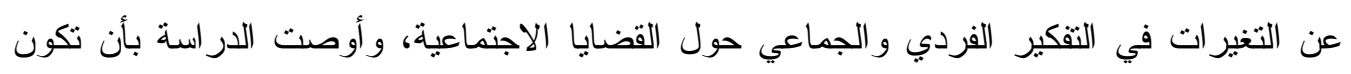

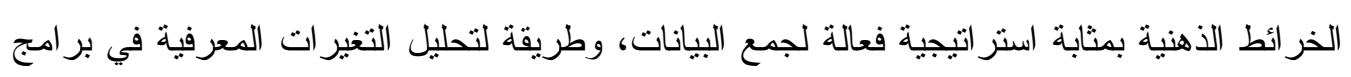

التتمية البيئية.

ويعتبر مجال حل المشكلات من أبرز المجالات التي يبرز فيها فعالية استخدام الخرائط الذهنية، حيث تساعد علي فهم صورة عامة عن الموضوع قيد الدراسة، و استكثاف تفاصيل أكثر بشأنه، وتتظيم المعلومات بطريقة يسهل تذكرها، وتعزيز القدرة على اتخاذ ملاحظات منظمة وألى وأكثر

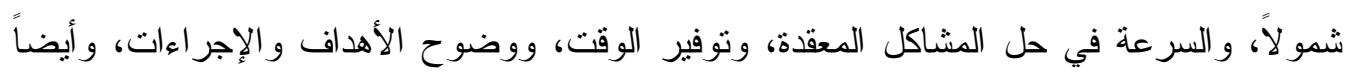

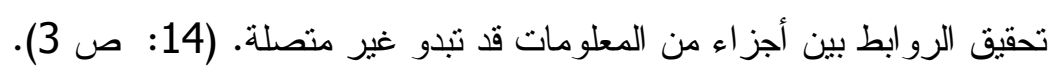

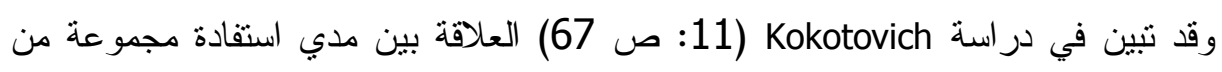

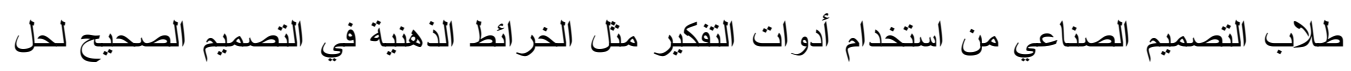
المشكلات وتوفير فرص أكبر لحلول مبتكرة للشكلة، وقدم الثكل غبر الهرمي للخريطة الذهنية

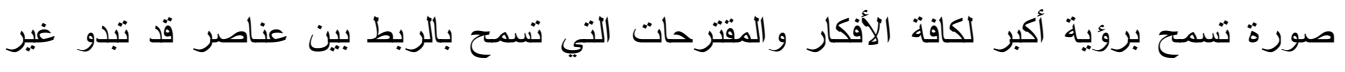

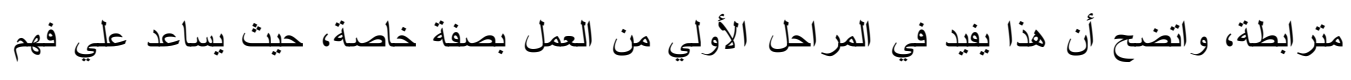
طبيعة المشكلة في ظل تعدد الأفكار وتعقيدها، والذي بتطلب القدرة علي ربط المشكلات الرئيسية

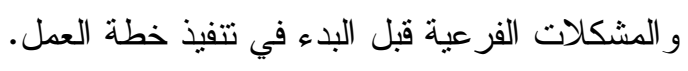
و علي مدي ثماني سنو ات طور Sicinski أكثر من ثلاثمائة نموذج اعتمد فيهم علي الخر ائط الذهنية لتساعد الفرد علي أن يفكر بصرياً ويكتسب مهارة حل المشكلات من خلال أساليب التفكير الفعالEffective Thinking والتي تناعد علي تحديد الخطوط العريضة لطريقة حل المشكلات

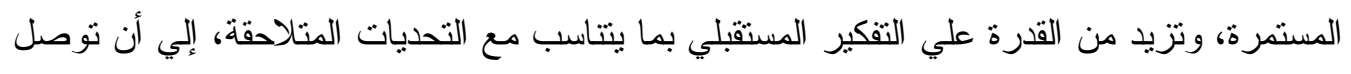
في عام 2009 إلي نموذج مطور لحل المشكلات، وساهم في نجاحه في تطوير النموذج، و واستخدامه

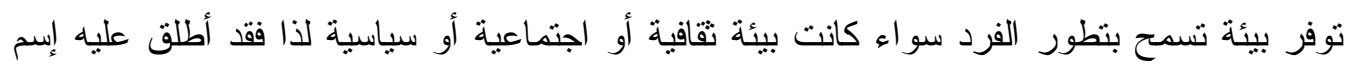

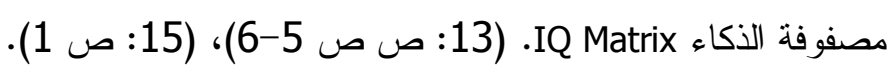


وتتضمن مصفوفة الذكاء لحل المشكلات خمسة أجزاء رئيسية، حيث يختص الجزء الأول بتحديد المشكلة Define the Problem و الغرض من هذا الجزء هو التعرف علي الجو انب التي تتعلق بالماضي المحيط بالمشكلة المطلوب إيجاد حل لها للتعلم من المحاو لات السابقة، وكذللك الجو انب التي تتعلق بالمشكلة في الحاضر حيث يساعد ذلك في تحديد الظروف الحالية والصعوبات المحتمل من بن

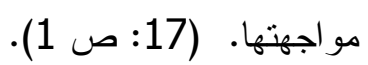
و الجزء الثاني فيتعلق بفصص المشكلة Investigate The Problem بهدف الوصول لمزيد من الوضوح حول الوضع الر اهن للمشكلة، ومن الأهمية أن يتم تتظيم المعلومات بطريقة تساعد علي فهم الحقائق المحيطة بالمشكلة، وحتي لا يتت وضع استتناجات و افتز اضات غير و اقعية، ويمكن تجنب حدوث ذللك من خلال تقصي الحقائق حول أربعة عناصر رئيسية تحيط بالمشكلة، ويتعلق العنصر الأول بنشأة المشكلة من حيث بداية وكيفية ومدي تكر ار حدوثها، ويتعلق الثاني بالإيجابيات المرتنطة

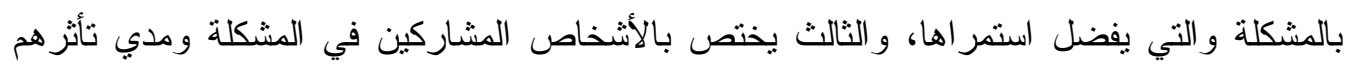

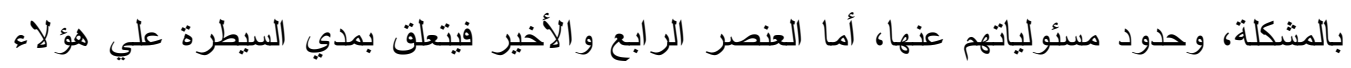

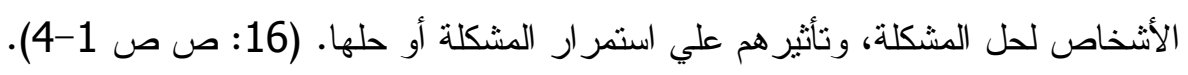

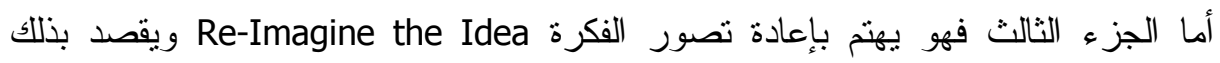
استخدام الأفكار الني نم الوصول إليها لتوليد مدي واسع من الحلول للمشكلة المطروحة من خلال أساليب التفكير العفوي و التفكير الإبداعي لتحديد البديل المناسب لحل المشكلة. (18: ص 1 1). ويتعلق الجزء الر ابع من مصفوفة الذكاء بتصميم خطة العمل Engineer Plan of Action

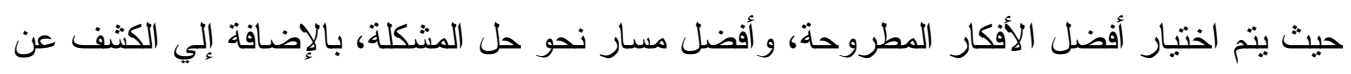

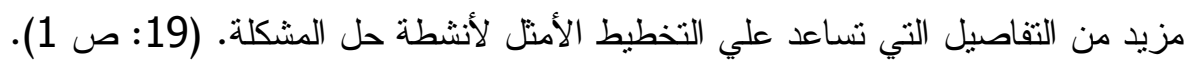

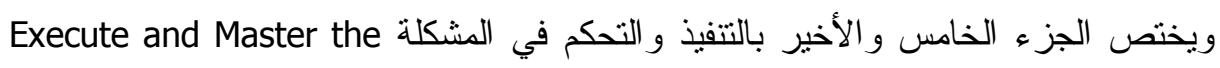

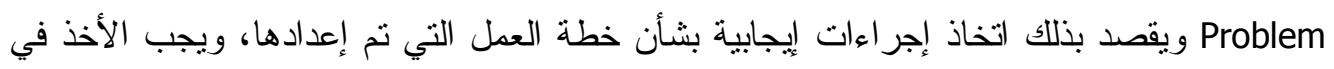
الاعتبار التعلم قدر الإمكان من الخبرات السابقة غير الموفقة، وهو أمر عادة يتجاهله المعنيين بحل بلدي

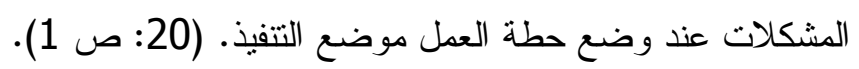

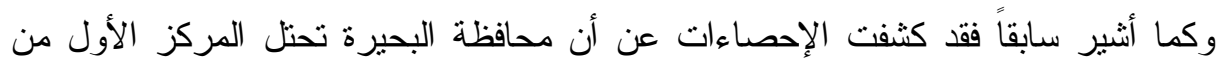
حيث الكمية المنتجة من قش الأرز، وأوضحت أيضاً عدم نتاسب الكمية المنتجة مع كميات فش الأن الأرز المستهدفة بأنشطة التدوير بالمحافظة، مما يشير إلي أن المشكلات التي نو اجه الزراعة واع في هذا المجال

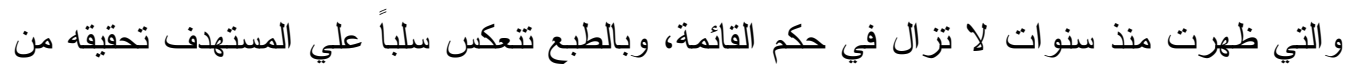
عوائد اقتصادية، واجتماعية، وبيئية لتتفيذ أنشطة تدوير قش الأرز، وقد فئن تتعلق هذه المشكلات

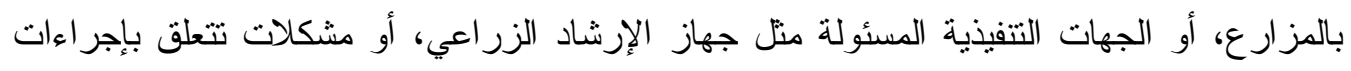
تتفيذ أنشطة تدوير قش الأرز، أو بإجر اءات التعاون مع جهات أخري أو غير ها من المشكلات.

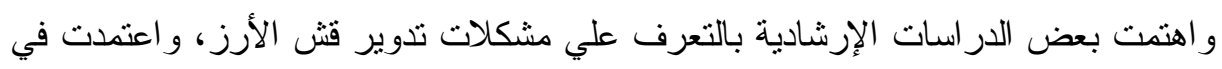

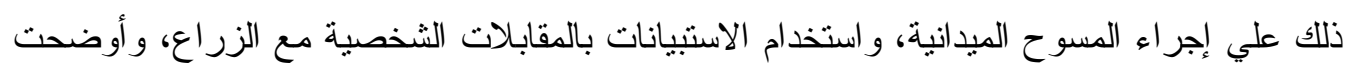

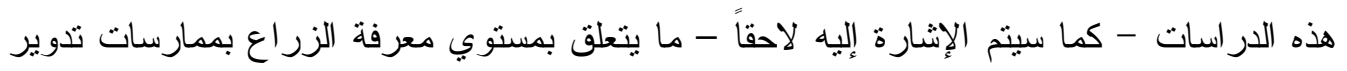


قش الأرز، وأهم المشكلات التي تواجهه في هذا المجال، وهنا يتبادر إلي الذهن الحاجة إلي اتباع

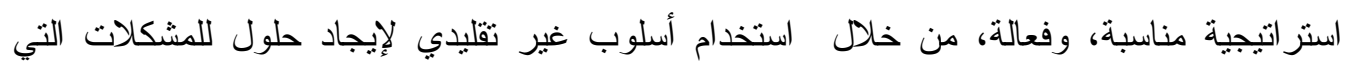

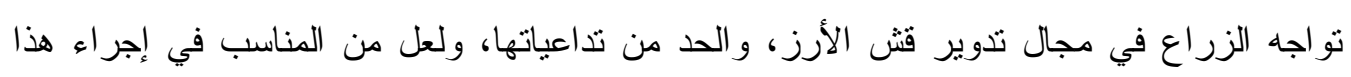

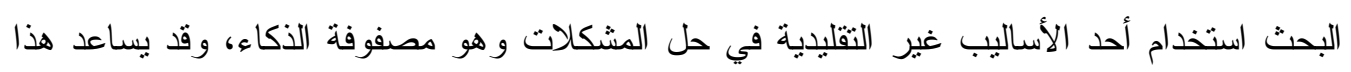

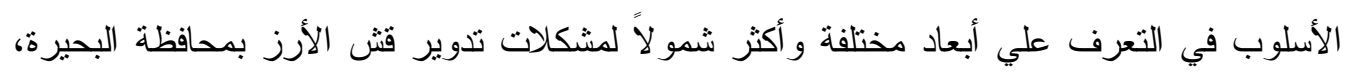

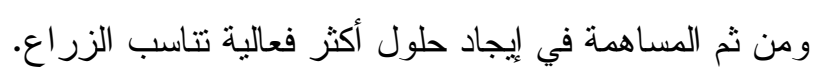

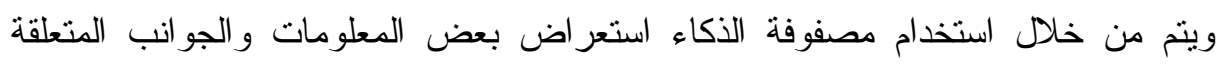

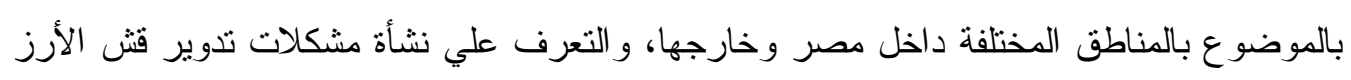

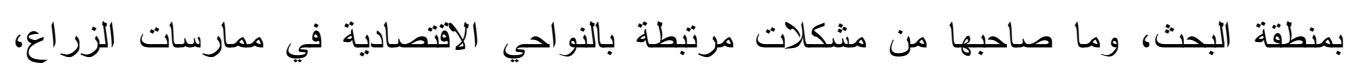

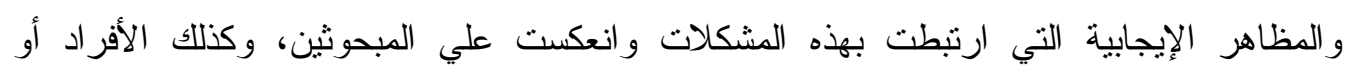

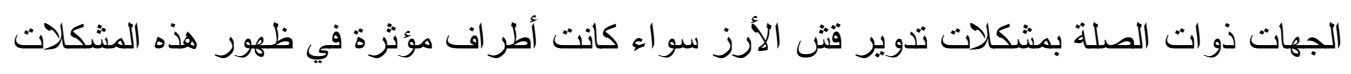

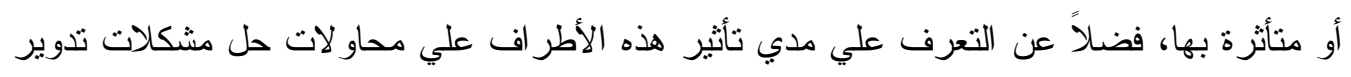
قش الأرز بمنطقة البحث.

لذا فالبحث يحاول الإجابة علي بعض التساؤلات التالية: ما هي أهم جو انب مشكلات تدوير

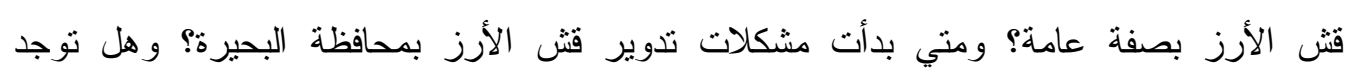

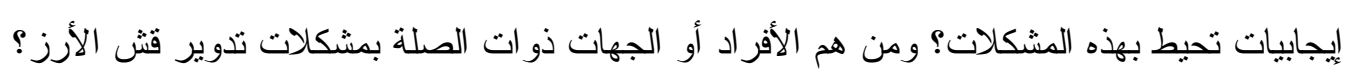

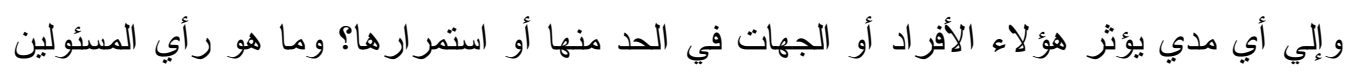

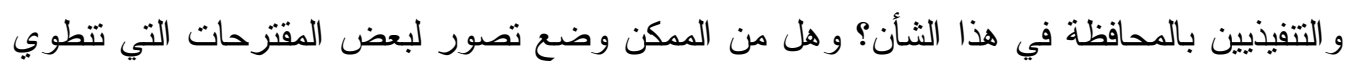

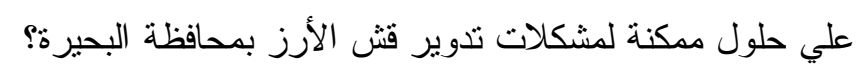

\section{أهمبة البحث}

مما لا شك فيه أن اختلاف الموضوعات الزر اعية في طبيعتها وشدتها يستتبعه اختلاف في

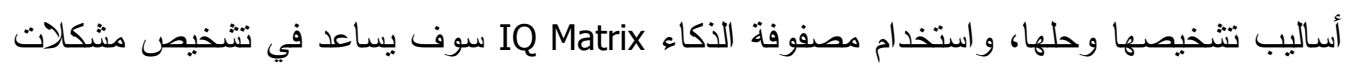
تدوير قش الأرز، بالإضافة إلي إمكانية وضع الخطط المناسبة لحل هذه المشكلات، وذلك من خلال

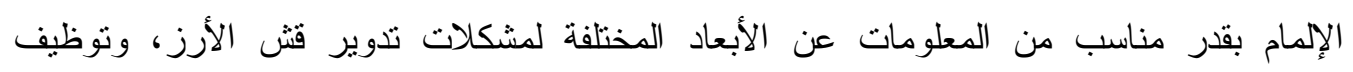

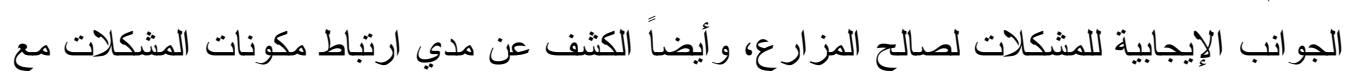

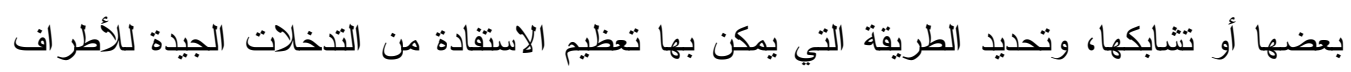

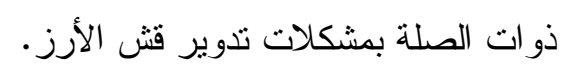

\section{أهد (اف البحث}

1- استخلاص أهم جو انب مشكلات تدوير فش الأرز .

2- التعرف علي الوضع الراهن لمشكلات تدوير قش الأرز من حيث نشأتها، و الجو انب الإيجابية

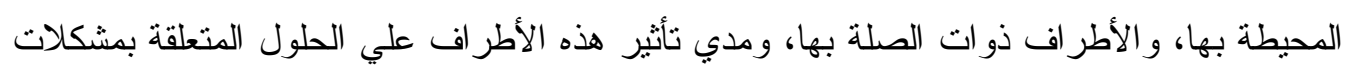
تدوير قش الأرز من وجهة نظر زراع الأرز بمحافظة البحيرة. 
3- التعرف علي آراء المسئولين و التتفيذيين من جهاز الإرشاد الزراعي في مشكلات تدوير قش الأرز بمحافظة البحيرة.

\section{الطريقة البحثية \\ تشتمل الطريقة البحثية على مجالات البحث ، وأسلوب جمع البيانات. مجالات البحث}

أُجري البحث بمحافظة البحيرة، وتم الاسترشاد ببيان الكميات المستهدفة لتذوير فش الأرز

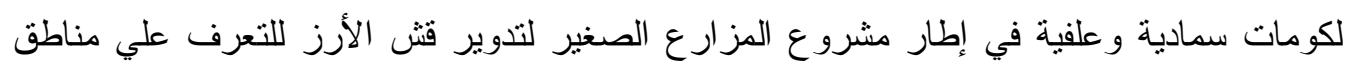
تتفيذ أنشطة تدوير فش الأرز بالمحافظة، وتبين أن هناك ثلاثة مراكز إدارية تحتل المرتبة الأولي الثي

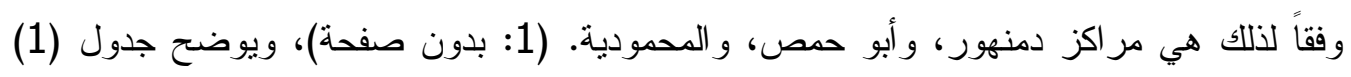

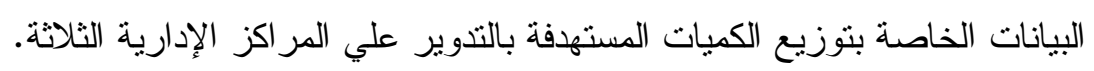

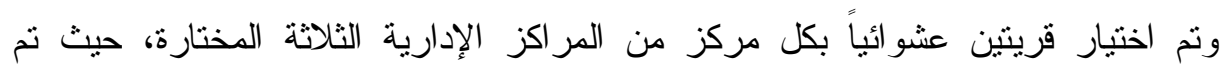

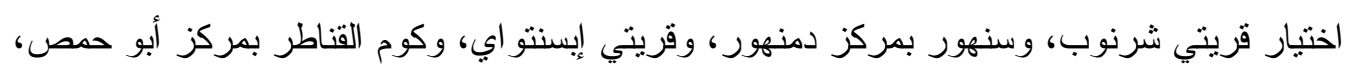

$$
\text { وقريتي أريمون القصر ، وكفر نكلا بمركز المحمودية. }
$$

جدول (1): توزيع كميات قش الأرز المستهرفة بالتدوير

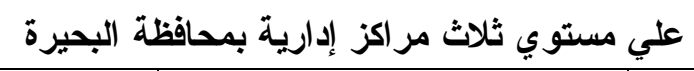

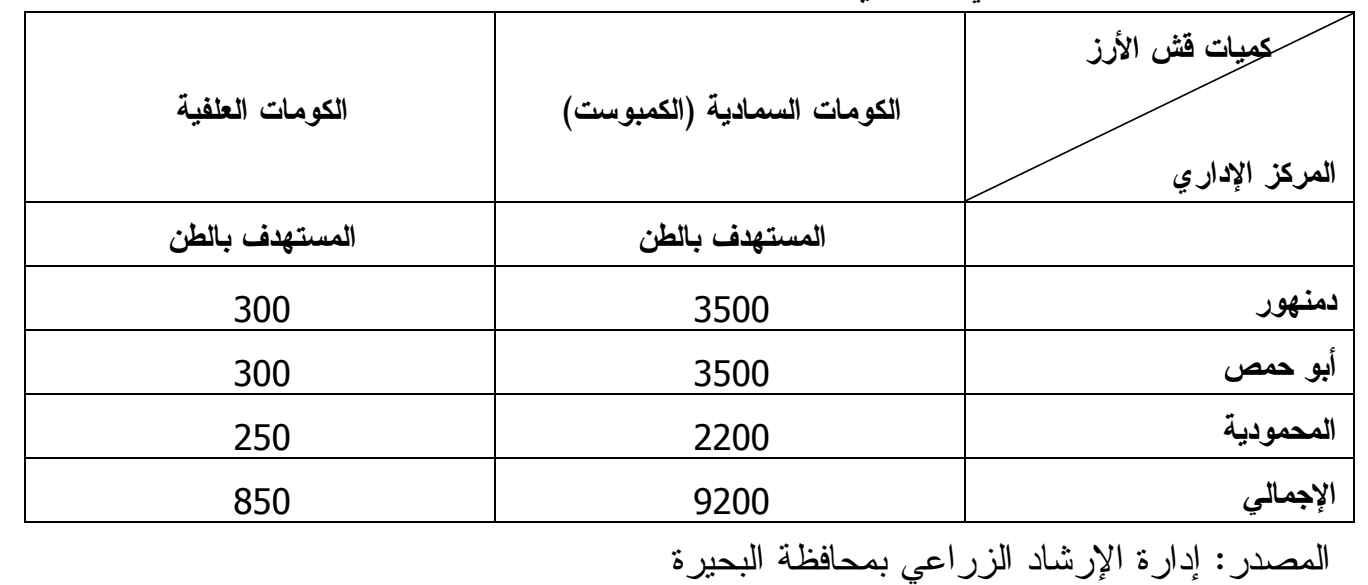

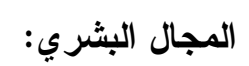

تم جمع البيانات باستخدام المجموعات النقاثنية بو اقع مجموعة من الزر اع منففي الكومــات

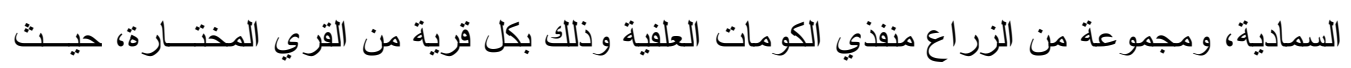

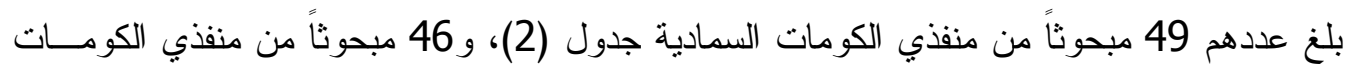

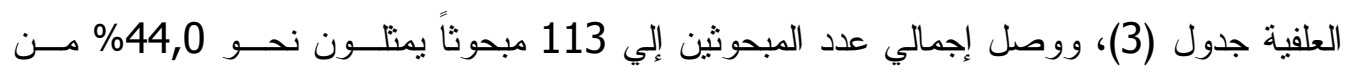

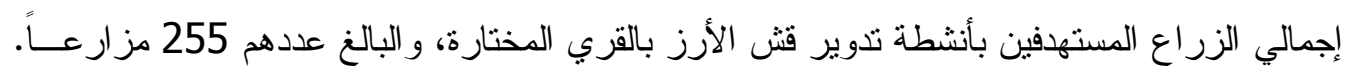


جدول (2): توزيع الزراع منفذي الكومات السمادية والزراع

المبحوثين علي مستوي المراكز الإدارية والقري المختارة بمحافظة البحيرة

\begin{tabular}{|c|c|c|c|c|c|c|c|}
\hline \multirow[b]{2}{*}{ الإجمالي } & \multicolumn{2}{|c|}{ المحمودية } & \multicolumn{2}{|c|}{ أبو حمص } & \multicolumn{2}{|c|}{ دمنهور } & المركز الإداري \\
\hline & كفر نكلا & أريمون & القتاطر & إبسنتواي & سنهور & شرنوب & \\
\hline 150 & 15 & 41 & 37 & 22 & 16 & 19 & الكومات السمادية لــز منفــي \\
\hline 49 & 7 & 9 & 8 & 8 & 9 & 8 & الكومات السمادية المبحثين منفذي \\
\hline
\end{tabular}

المصدر : إدارة الإرشاد الزر اعي بمحافظة البحيرة

جدول (3): توزيع الزراع منفذي الكومات العلفية والزراع

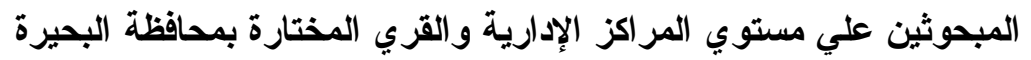

\begin{tabular}{|c|c|c|c|c|c|c|c|}
\hline \multirow[b]{2}{*}{ الإجمالي } & \multicolumn{2}{|c|}{ المحمودية } & \multicolumn{2}{|c|}{ أبو حمص } & \multicolumn{2}{|c|}{ دمنهور } & المركز الإداري \\
\hline & كفر نكلا & أريمون & القتاطر & إبسنتو اي & سنهور & شرنوب & \\
\hline 105 & 12 & 26 & 20 & 12 & 13 & 22 & علدم الــزراع منفــــي \\
\hline 64 & 9 & 10 & 11 & 12 & 12 & 10 & الكومات العلقية المبحثين منفذي \\
\hline
\end{tabular}

المصدر : إدارة الإرشاد الزر اعي بمحافظة البحيرة

هذا بالإضافة إلي استيفاء بيانات بحثية عن طريق المقابلات المتعمقة مع ثمانية من قيــادات

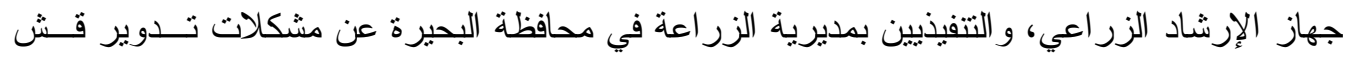

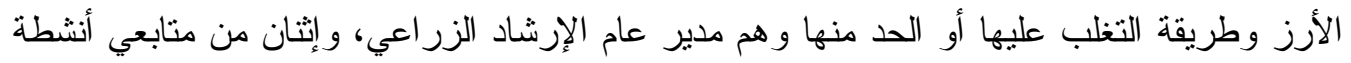

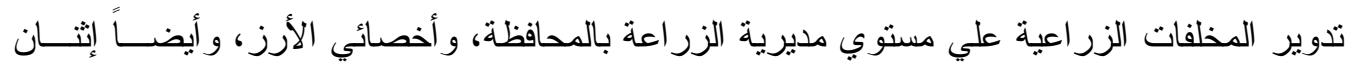

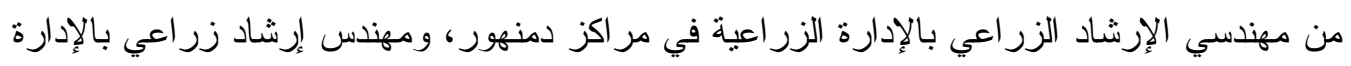
الزر اعية بكل من مركز أبو حمص، ومركز المحمودية.

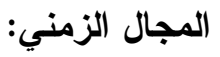
تم جمع البيانات البحثية خلال شهري فبر اير ومارس 2018. 


$$
\text { أسلوب البحث وأدو (ته }
$$

يستهدف البحث استخدام مصفوفة الذكاء IQ Matrix كأحد أساليب التفكير الفعال لحل واتله المشكلات في تشخيص مشكلات تدوير فش الأرز بمحافظة البحيرة، وتتضمن مصفوفة الذكاء خمسة

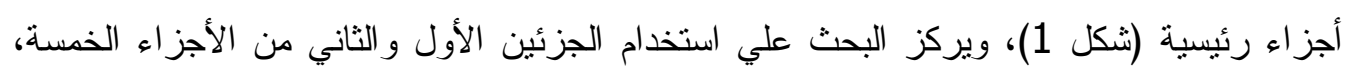

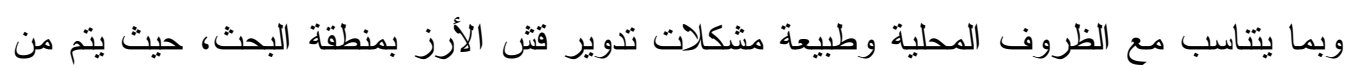
خلال الجزء الأول من مصفوفة الذكاء و المعني بتحديد المشكلة Define the Problem استعر اض لفئل بعض الدراسات التي تتاولت سلوك الزراع في مجال تدوير قش الأرز بمصر وبعض الأول الدول الأخري، كما يتم من خلال الجزء الثاني والمتعلق بفحص المشكلة Investigate The Problem التعرف علي معلومات المبحوثين حول مشكلات تدوير قش الأرز التي تواجههم وذلك فيما يتعلق

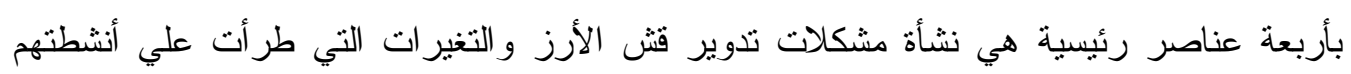

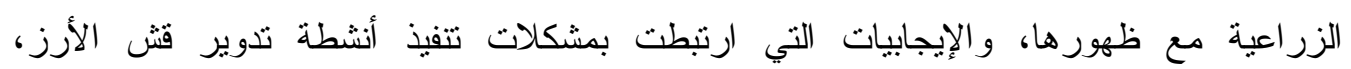

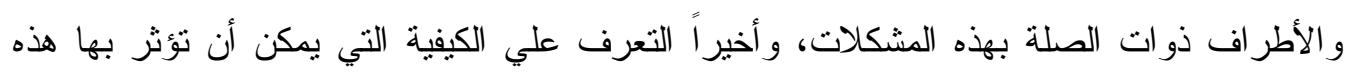
الأطر اف في حل مشكلات تدوير قش الأرز بمنطقة البحث.

وتتطلب الأجزاء الثلاثة الباقية والخاصة بإعادة تصور الفكرة Re-Imagine the Idea،

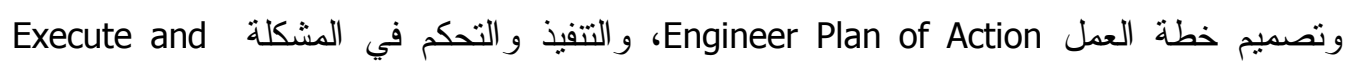
Master the Problem

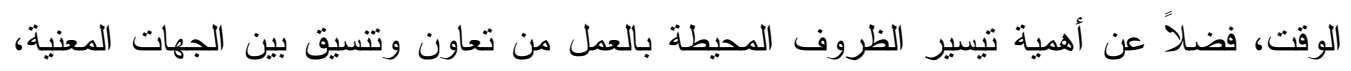
و لأنها منطلبات يصعب استيفاؤها في هذا البحث، لذا فقد يكون الدور الأكثر فعالية في استكمال

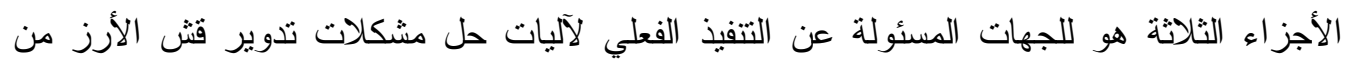

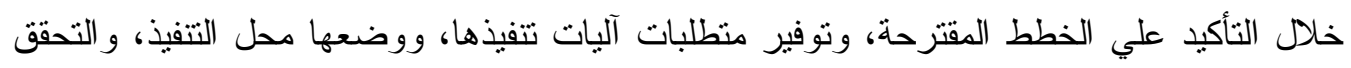

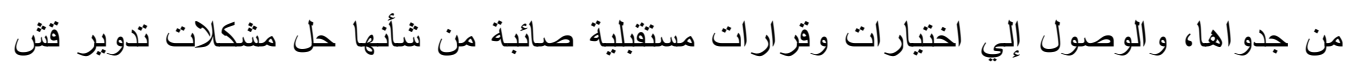

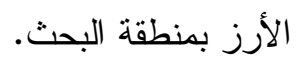

كما نم الاعتماد في البحث علي الأسلوب الكيفي في جمع البيانات البحثية، حيث تتحقق

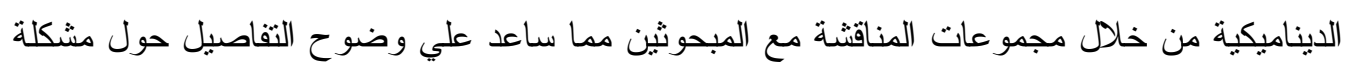
البحث، بالإضافة إلي عرض نتائج البحث بصورة تعبر عن آراء المبحوثين وانفعالاتهم أثناء 


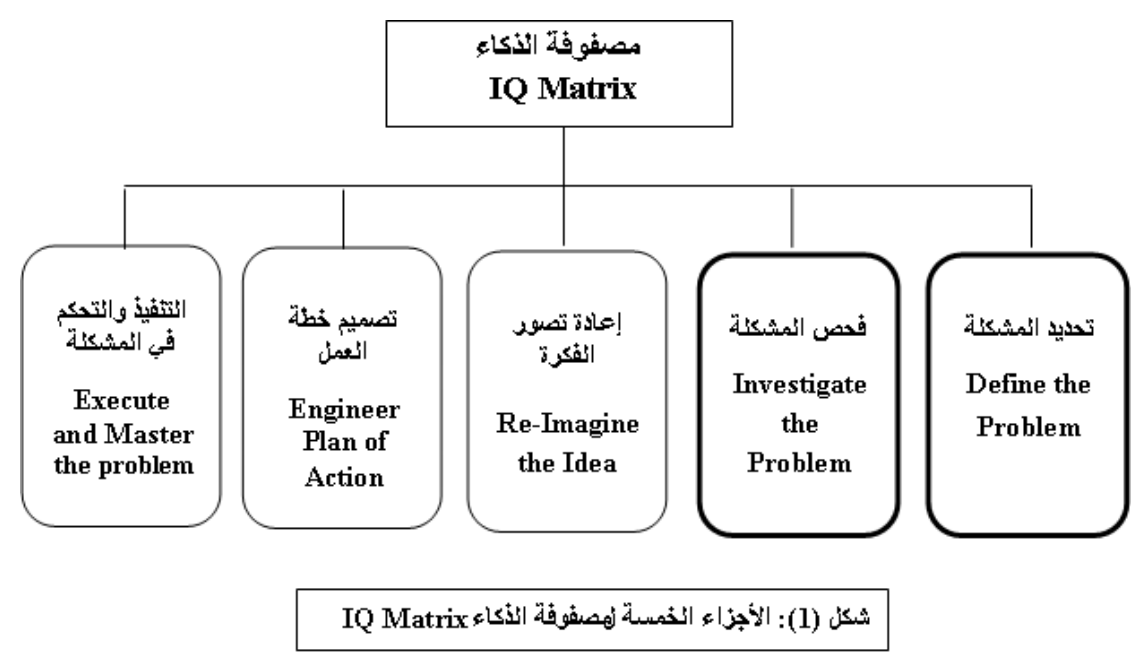

أسلوب جمع البيانات

غالباً ما يتم إجر اء تدوير قش الأرز بمنطقة البحث من خلال أنشطة الإيضاح العملي في

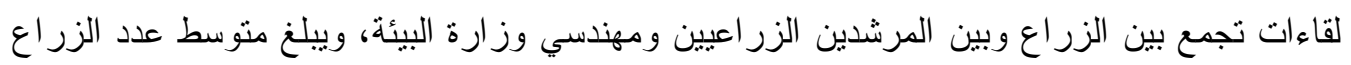

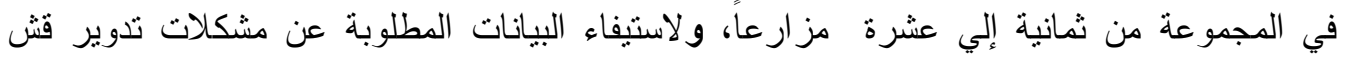

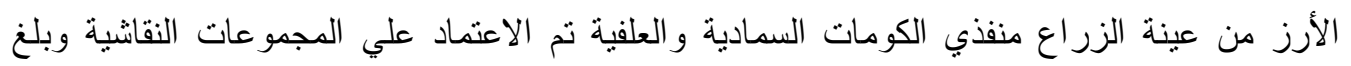
عددها 12 مجموعة، وتضمن دليل المناقشة الذي تم إعداده لهذا الغرض العناصر التالية: 1- بداية ظهور مشكلات تدوير قش الأرز .

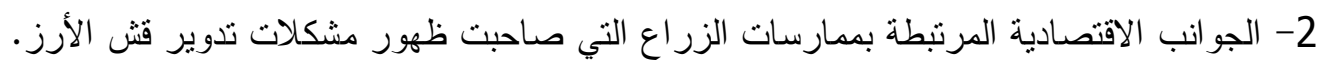
3- مميز ات أنشطة تدوير قش الأرز التصن.

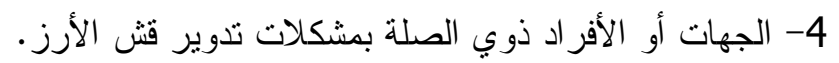

5- الجهات المعنية أو الأفراد المسئولين عن حل أو الحد من المشكلات التي تو اجه الزر اع في مجال تدوير قش الأرز، وكذلك الجهات التي يمكن أن تساهم مستقبلاً في حل مشكلات تدوير قش الأرز بالمحافظة. وبالنسبة للمسئولين و التنفيذيين من جهاز الإرشاد الزر اعي فـــ مديريــة الزر اعــة و المر اكــز

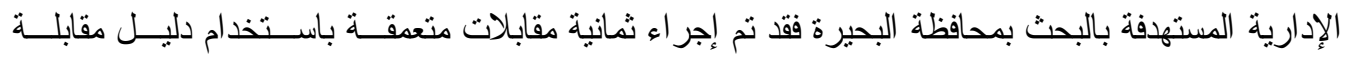

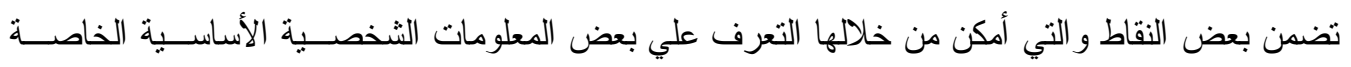

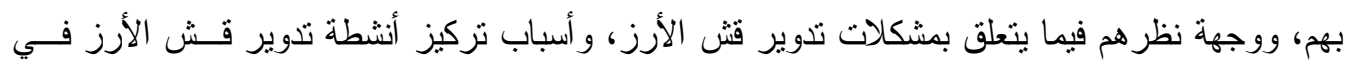

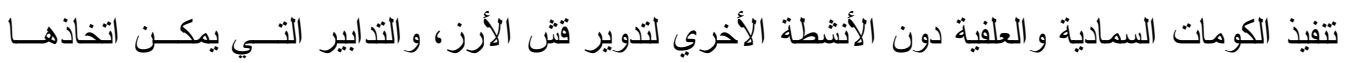

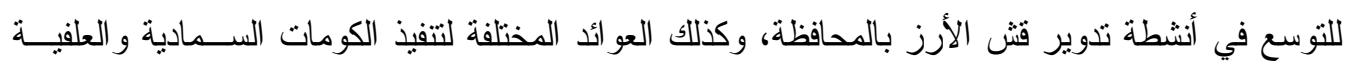

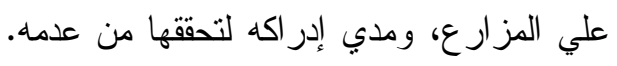




\section{النتائج ومناقشتها}

أولاً: استخلاص أهم جوانب مشكلات تدوير قش الأرز

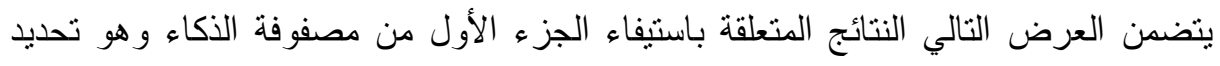

المشكلة Define The Problem، وذلك من خلال استخلاص بعض المعلومات المتعلقة بجوانب

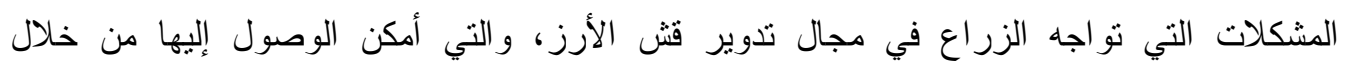

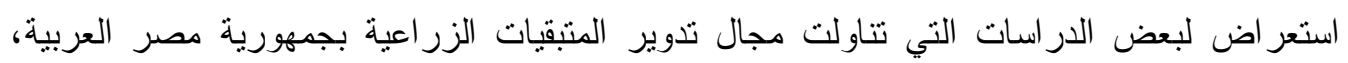

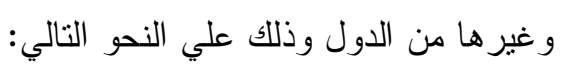
أوضحت دراسة إلهام قطب (8: ص صن صن 12، 20) و التي استهدفت التعرف على محددات تدوير المخلفات الزر اعية بمحافظتي الفيوم وبني سويف أن ما يقرب من نصف المبحوثين ذوى درجة دمان معرفة

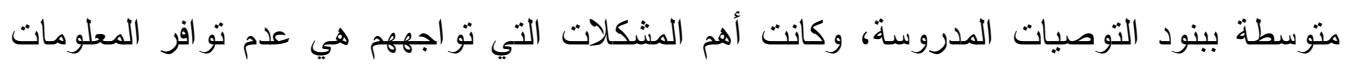
الكافية عن تدوير المخلفات الزراعية، وعدم متابعة المرشد الزراعى لهم، وعدم نو افر ماكينات الفرم

كما أظهرت در اسة عبد الله و آخرين (6: ص ص 278-283) أن حوالي نصف المبحوثين ببعض

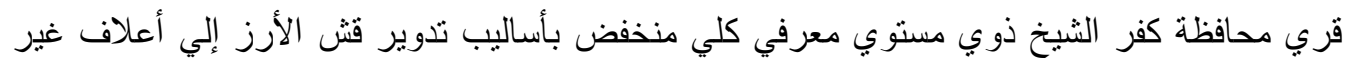

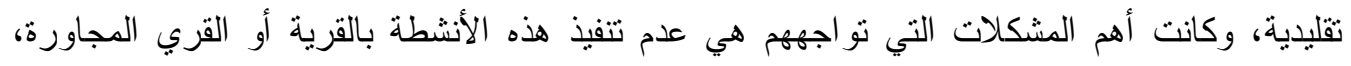
و عدم تو افر المكابس وماكينات الفرم، وغياب دور المرشد الزر اعي.

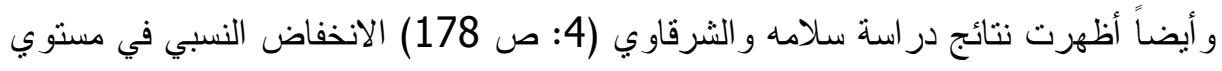
معرفة المبحوثين بمحافظتي الثرقية و الدقهلية بأساليب تدوير المخلفات الزراعية، وتبين أن أهم أهم

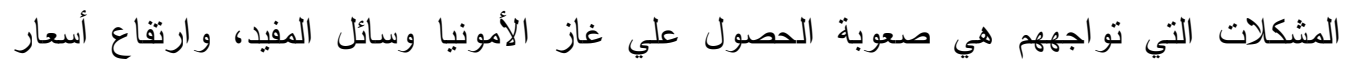
مستلزمات عمليات تدوير المخلفات الزراعية، وندرة النشرات الإرشادية و الأنشطة الإرشادية، وندرة توفر المكابس وماكينات الفرم. وكذلك أظهرت در اسة عز ام و آخرون و التي تمت بإحدي قري محافظة الدقهلية (7: ص 15)

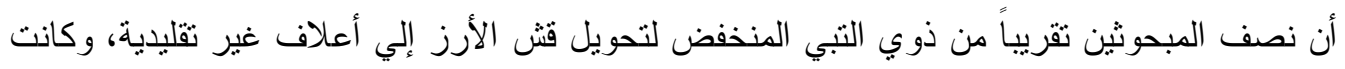

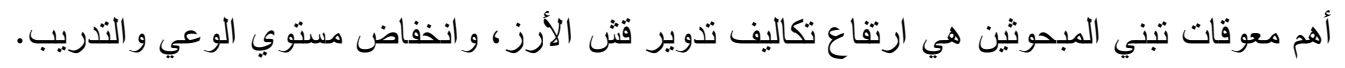
وبصفة عامة اتضح من العرض السابق أن ما يقرب من نصف المبحوثين بكل من الدر استات

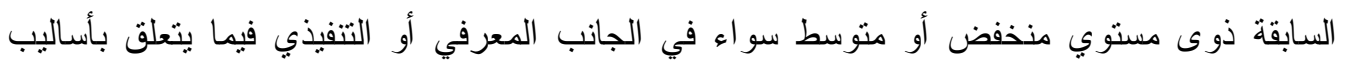

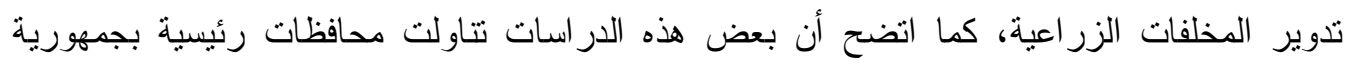
مصر العربية في زر اعة الأرز مثل كفر الثيخ، و الثرقية، والدقهلية ومن ثم فهي من أكبر المحافظات

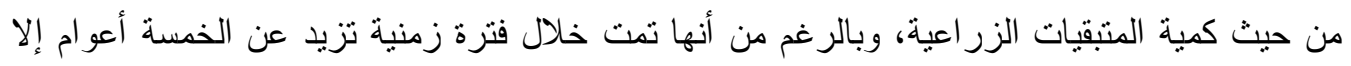
أن المشكلات التي تو اجه الزراع في مجال تدوير المتنقيات الزراعية بالمحافظات المدروسة منعددة ومتكررة.

وبمحاولة الحصول علي مزيد من المعلومات عن نفس الموضوع ببعض الدول الأخري

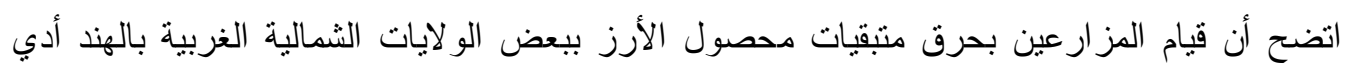


إلي تحول الأمر إلى مشكلة كبيرة، و أصبحت إدارة متبقيات محصول الأرز ذات أهمية قصوى في هذه

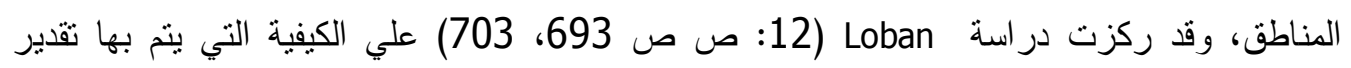

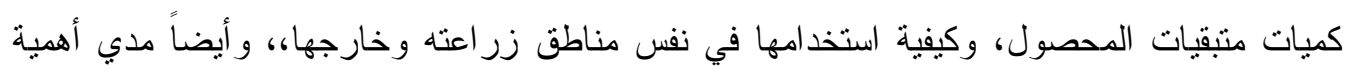

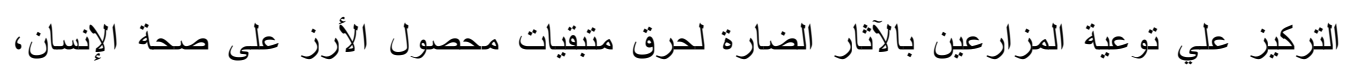

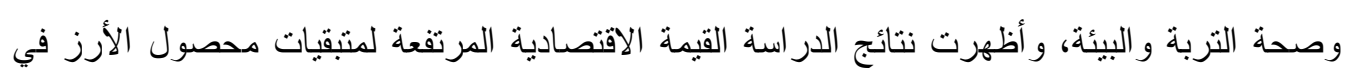
تغذية المانشية، وتوليد الوقود وغير ها من الاستخدامات، كما تطرقت الدراسة للتعرف علي الآليات

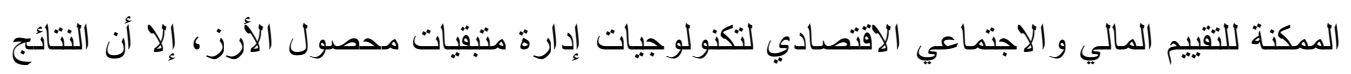

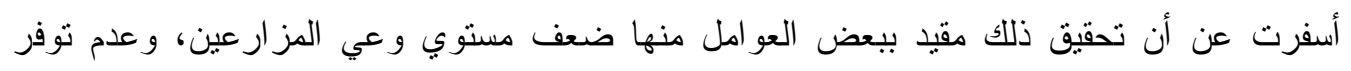

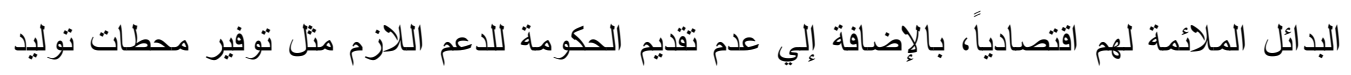

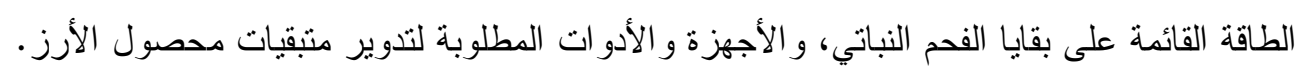

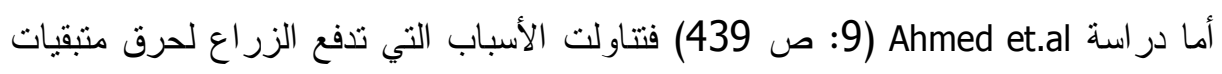

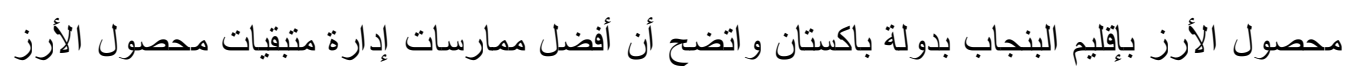

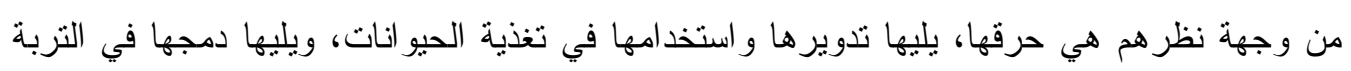
من أجل إعداد الأرض لزر اعة المحصول التالي، حيث تزيد تكلفة تدوير متنقيات المحصول بالنسبة لهم

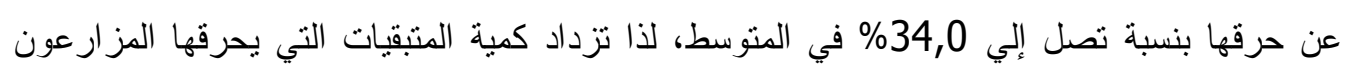

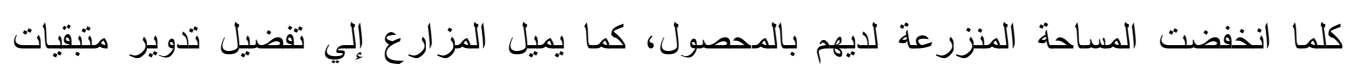

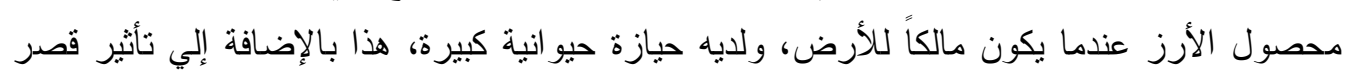

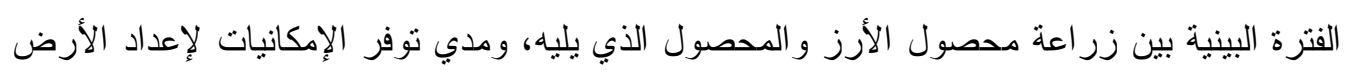
للمحصول الثالي.

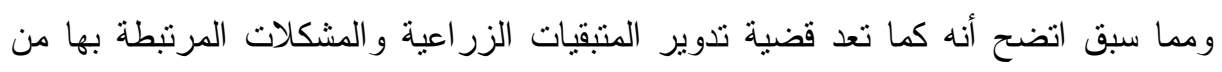

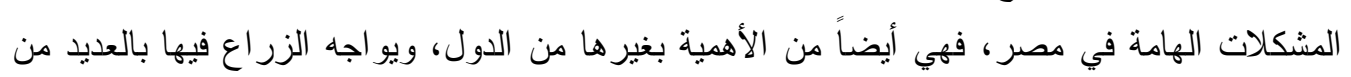

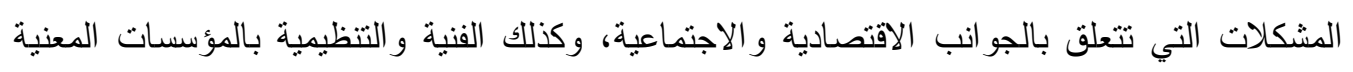
بهذا المجال هناك. ثانياً: التعرف علي الوضع الراهن لمشكلات تدوير قش الأرز من وجهة نظر الزراع المبحوثين بمحافظة البحيرة

بختص العرض الثالي بنتائج الجزء الثاني من مصفوفة الذكاء و المتعلق بفحص المشكلة Investigate The Problem وجود اتفاق عام بين المبحوثين بالمجموعات النقاشية المختلفة بالقري المستهدفة حول البنود مدل

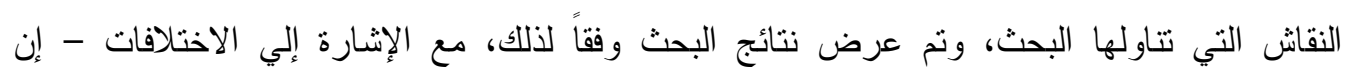
وجدت - بين المبحوثين الذين يقومون بتتفيذ الكومات السمادية و العلفية. 


\section{1- نشأة مشكلات تدوير قش الأرز}

يعتمد التشخيص الصحيح لمشكلة ما علي التعرف علي بداية حدوث هذه المشكلة، فمن المؤكد

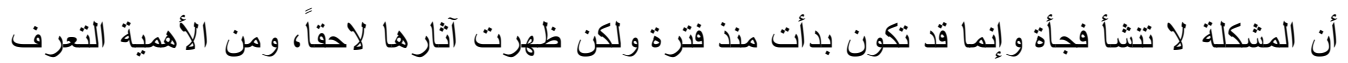
علي بداية ظهور هذه المشكلات، والمشكلات التي صاحبتها في ممارسات الزر اع المبحوثين.

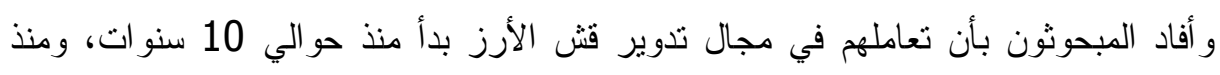

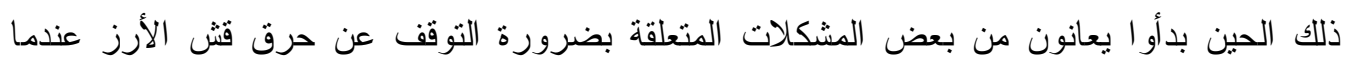

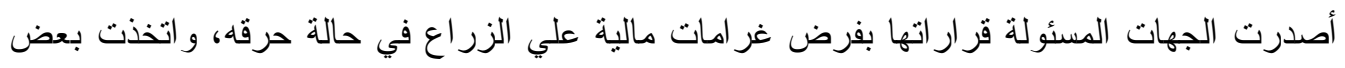

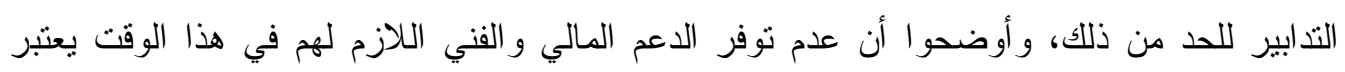

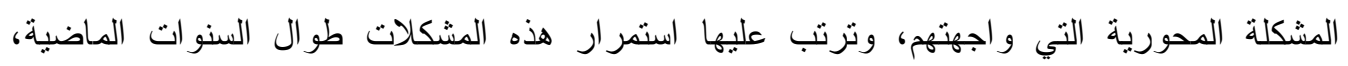
بالإضافة إلي ظهور بعض المشكلات المستجدة، وأمكن إيجاز المشكلات الرئيسية التي تو اجنها

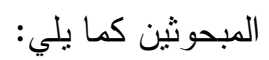

\section{* المبحوثون منفذو الكومات السمادية لية}

- أثنار غالبية المبحوثين إلي ارتفاع أسعار مستلزمات تتفيذ الكومات السمادية، وأيضاً ارتفاع أسعار

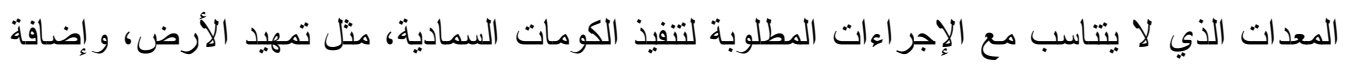

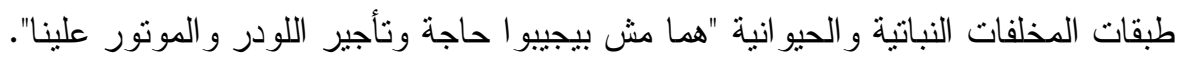

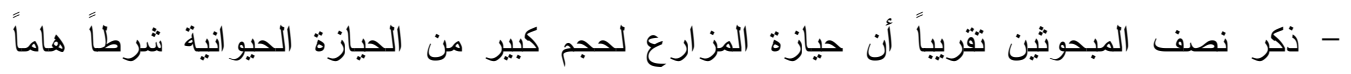

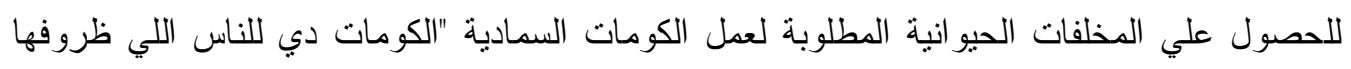
مريحة".

\section{* المبحوثون منفذو الكومات العلفية}

- أجمع المبحوثون علي عدم توفر مستلزمات تتفيذ الكومات العلفية، كما أفادت نسبة قليلة منهم بأن

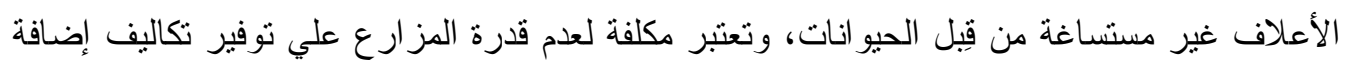

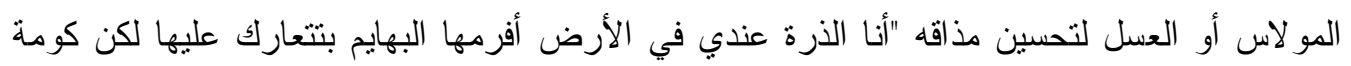
العلف بقش الأرز البهيمة بترفضها".

- يو اجه معظم المبحوثين بعدم توفر المكابس أو ماكينات الفرم بالجمعيات الزر اعية أو جهة حكومية لهونة

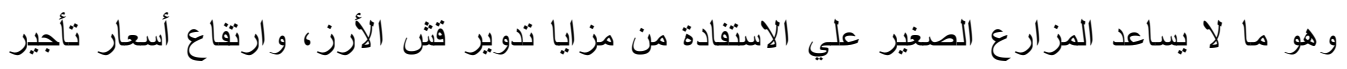

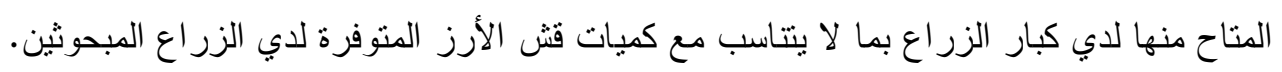

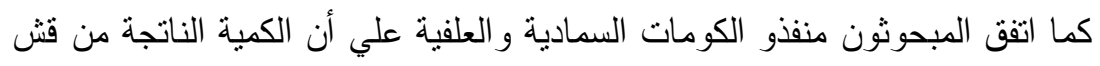
الأرز قلليلة نتيجة لصغر حجم حيازتهم الزر اعية، ومن ثم فهي لا تتناسب مع تكاليف نقلها لمركز

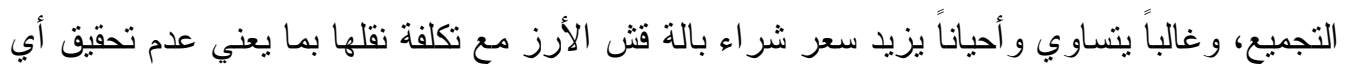
ربح للمز ارع، وكذلك ضعف قدرتهم علي التعاقد مع جهات النسويق المختلفة لصغر كميات قش الأرز لايهرم.

ومن الجدير بالإشارة إلي أن أحد المبحوثين أفاد بأن رغم اتفاقه مع أقر انه في أن صغر حجم

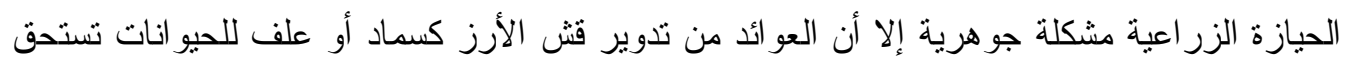


مواجهة مشكلاته "الناس مش فاهمة لو فهمت صح هاتعمل الكومات باهتمام أنا باعملها رغم كل

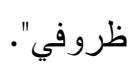
كما أمكن إيجاز أهم المشكلات المرتبطة بالنواحي الاقتصادية في ممارسات الزراع والتي صاحبت

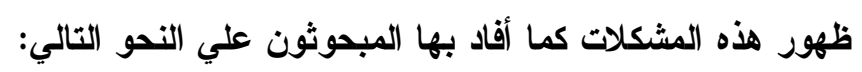

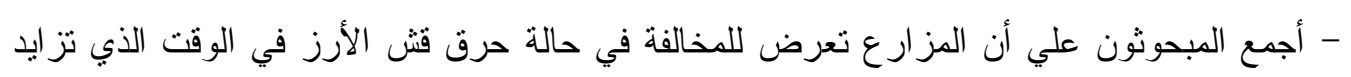

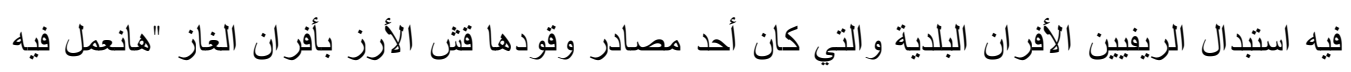

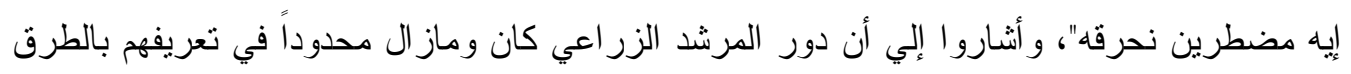

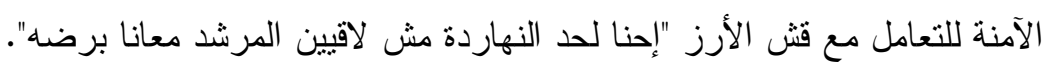

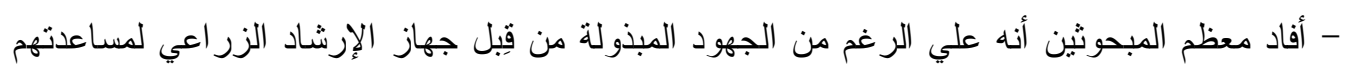

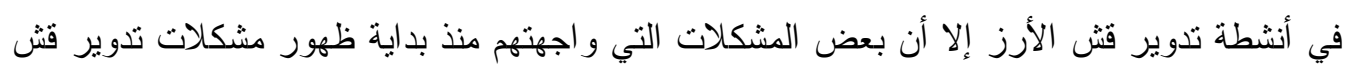

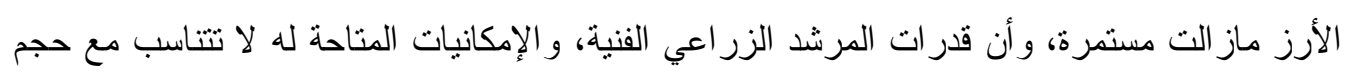
العمل المطلاوب منه في هذا الثأن. - تبين أن نسبة قليلة من المبحوثين علي وعي بأن أنشطة تدوير فش الأرز لا تقتصر علي الكومات

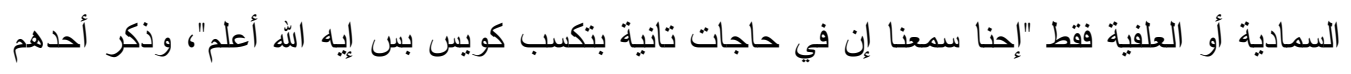

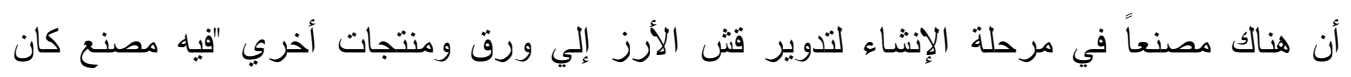

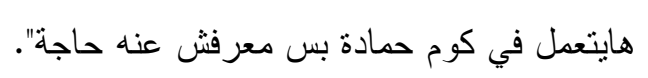

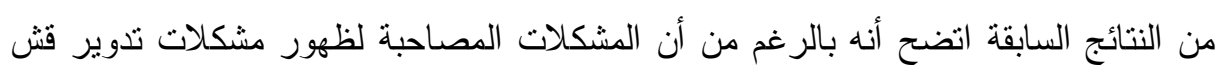

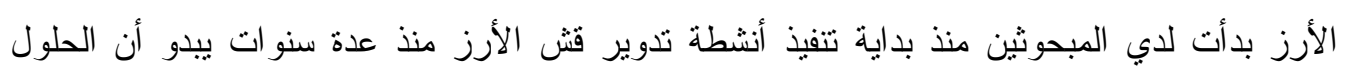

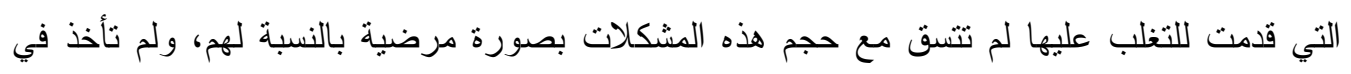

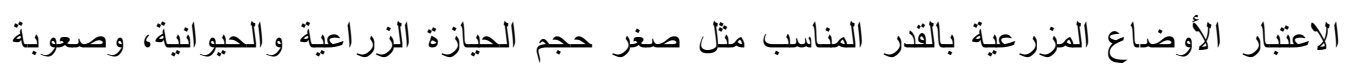

نوفير مستلزمات عمل الكومات السمادية أو العلفية، وارتفاع تكاليفها.

2- إيجابيات مشكلات تدوير قش الأرز من وجهة نظر الزراع المبحوثين بمحافظة البحيرة

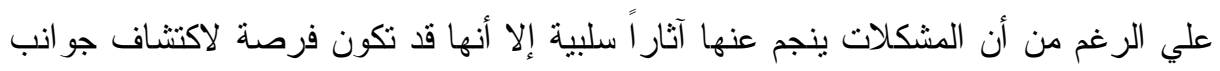

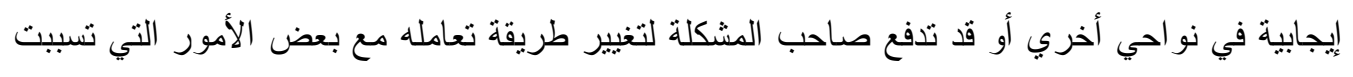
في حدوث المشكلة، وأثنار المبحوثون إلي بعض الانعكاسات الإيجابية علي أوضاعهم المزرعية أثناء

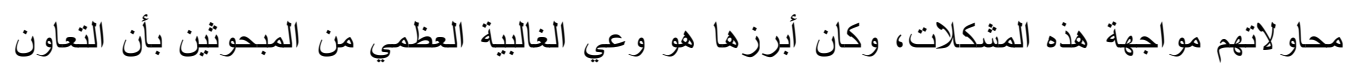

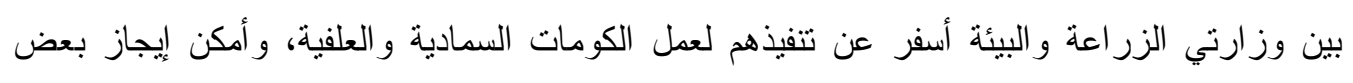

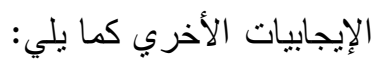
* المبحوثون منفذو الكومات السمادية - أفادت نسبة كبيرة من المبحوثين أنهم كانو الظنون أنهم علي

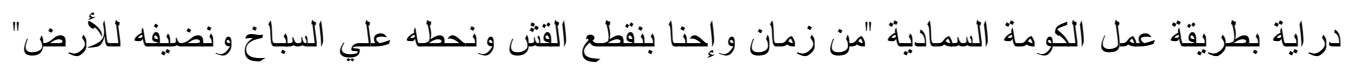

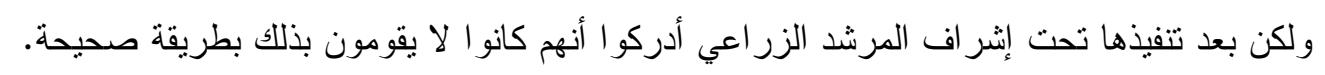


- أكد معظم المبحوثين أنه بالرغم من صعوبة توفير المستلزمات المطلوبة لتتفيذ الكومات السمادية إلا

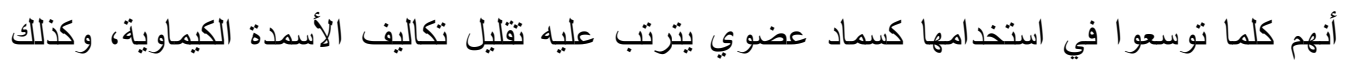

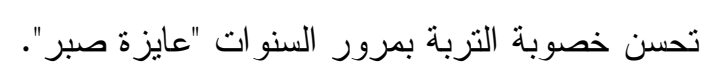

* المبحوثون منفذو الكومات العلفية

- أفاد نحو نصف المبحوثين أنهم بعد عدة تجارب في تتفيذ الكومات العلفية أصبحوا قادرين علي

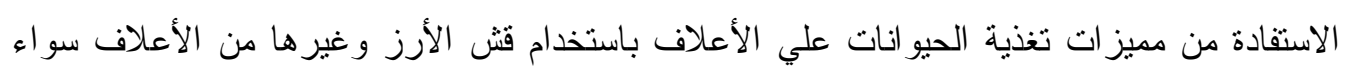

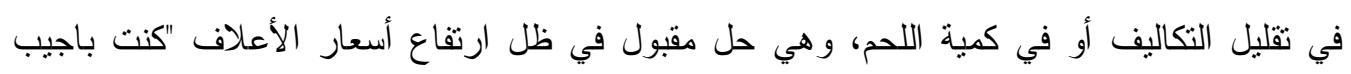

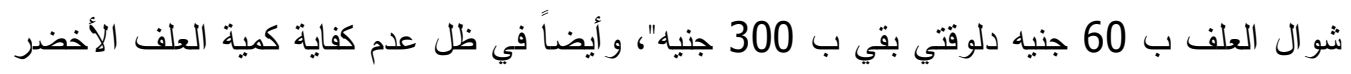
كنتيجة لتقلص حجم الحيازة الزر اعية.

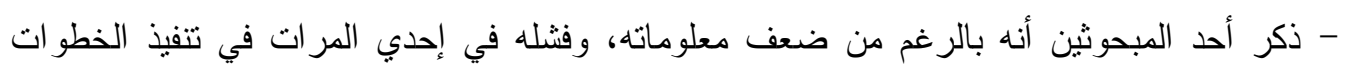

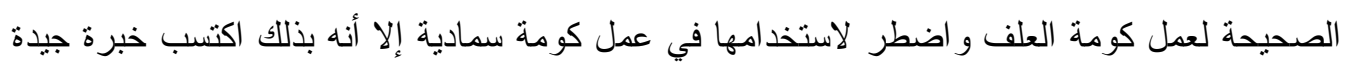
جنبته الخسارة مجدداً. - أفاد حو الي ثلث المبحوثين بتو افر بعض فرص العمل للثباب أثناء موسم الحصاد وجمع قش الأرز .

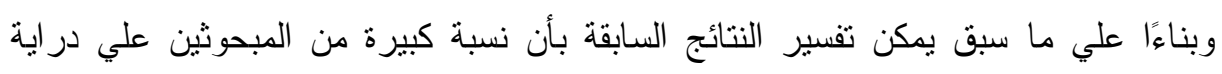

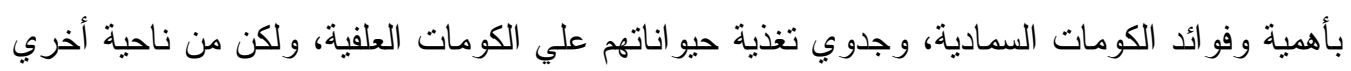

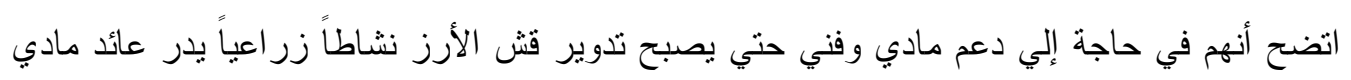

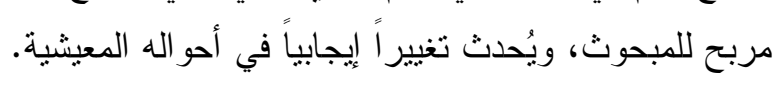

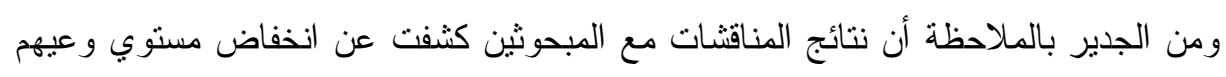

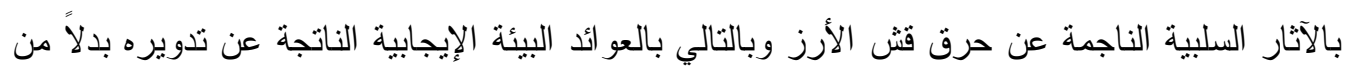

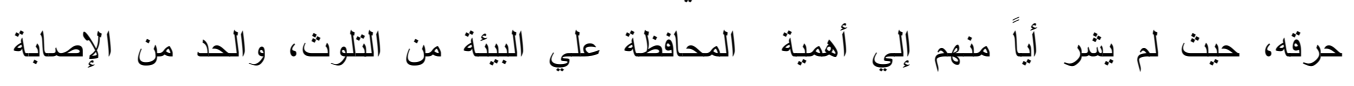

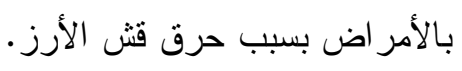

3- الأطراف ذات الصلة بمشكلات تدوير قش الأرز من وجهة نظر الزراع المبحوثين بمحافظة البحيرة

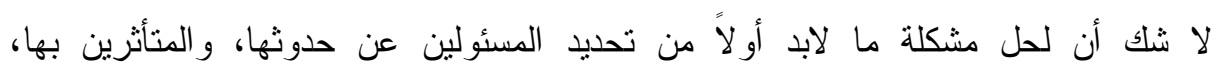

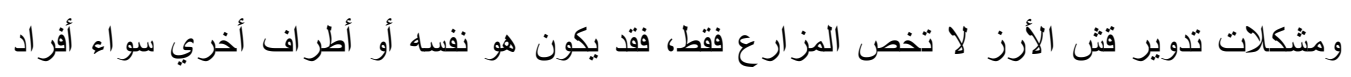
أو جهات مسئولة معه عن ظهور هذه المشكلات أو الحد منها أو حلها.

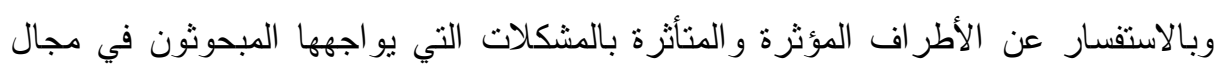

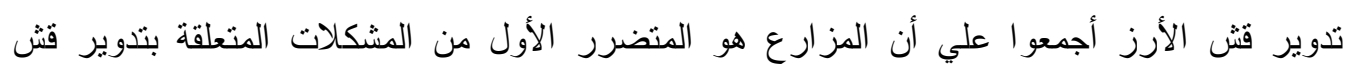
الأرز ، حيث يعانون من عدم تتاسب الأساليب المتبعة مع صغر حجم الحئ الحيازة الزر اعية و الحيو انية لديهم

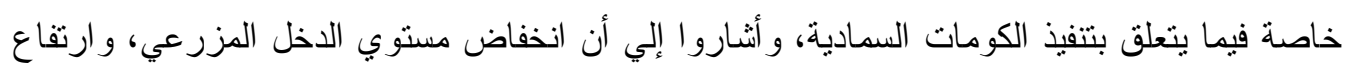
قيمة الغر امات المالية في حالة حرق قش الأرز تتعكس سلباً علي الأحو ال المعيشية لأفر اد أسر هم.

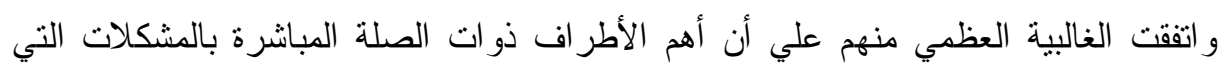
تواجه الزراع في أنشطة تدوير فش الأرز هي جهاز الإرشاد الزراعي من خلال تلفئ التفيذ الكومات

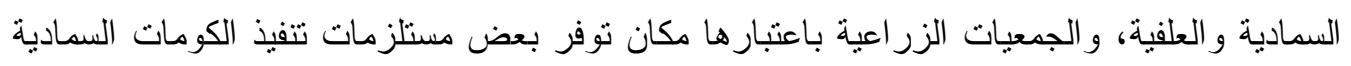


و العلفية التي يمدها بها جهاز الإرشاد الزراعي، كما أثنار أكثر من ثلثيهم إلي وزارة البيئة والتي

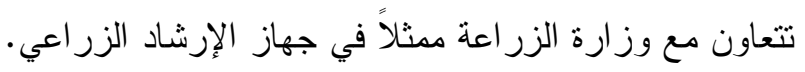

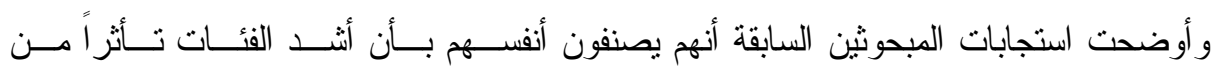

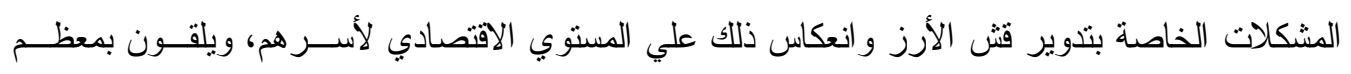

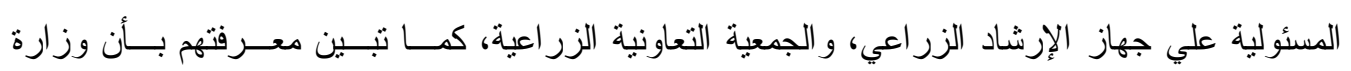

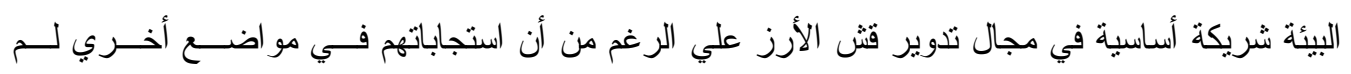

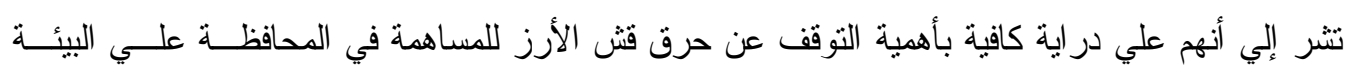

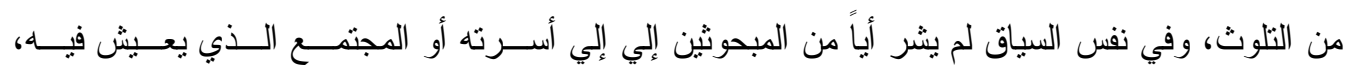

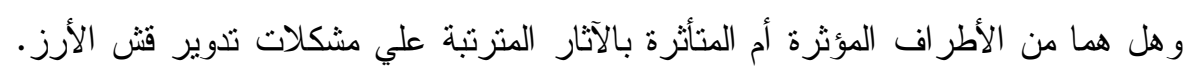

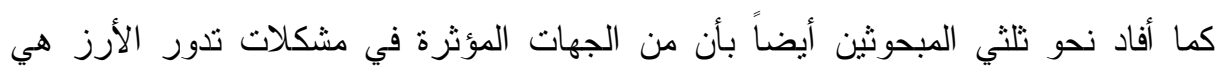

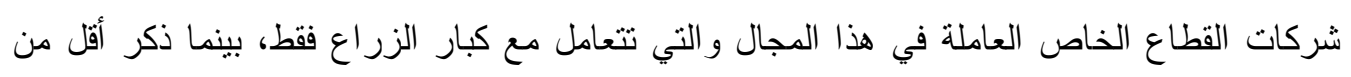

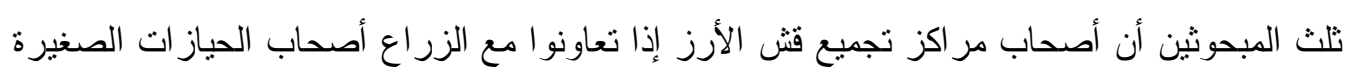

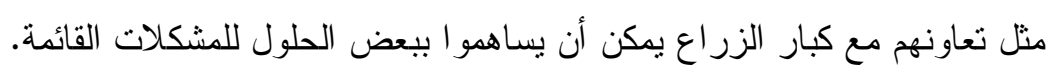

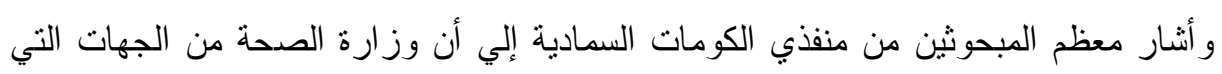

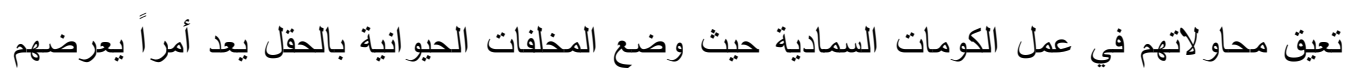

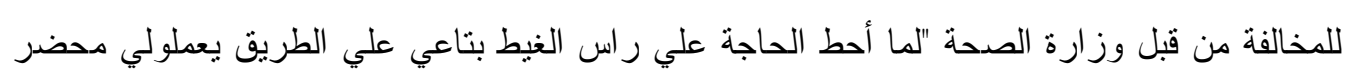
أو مال أوديها فين".

4- مدي تأثير الأطراف ذات الصلة علي الحلول المتعلقة بمشكلات تدوير قش الأرز من وجهــة نظــر زراع الأرز المبحوثين بمحافظة البحيرة

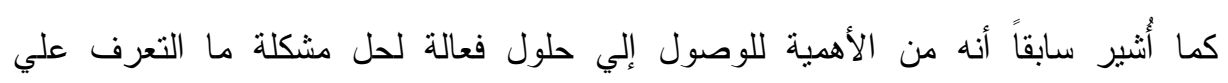

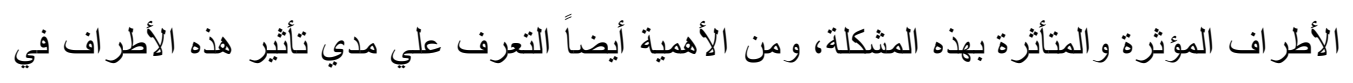
توفير آليات الحد من المشكلة.

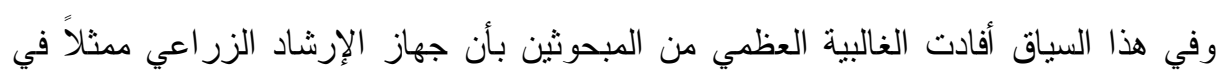

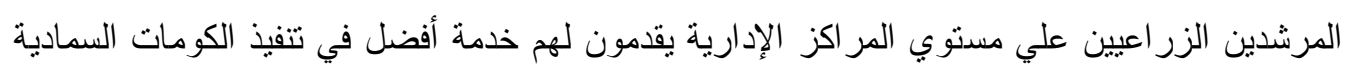

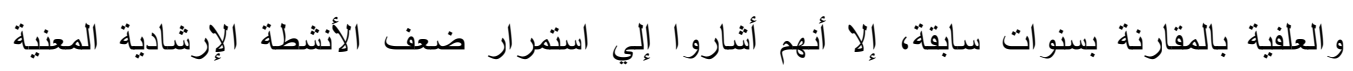

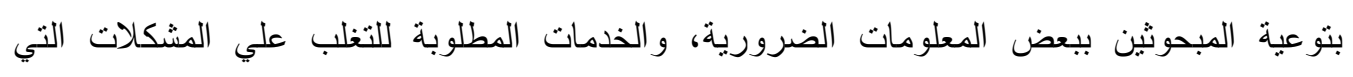

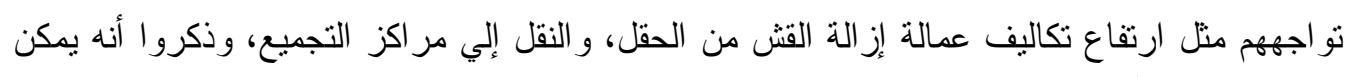

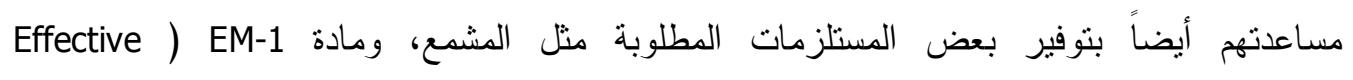

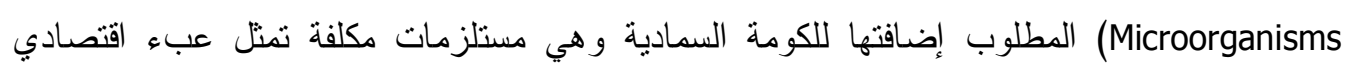
علي صغار الزراع.

كما أثنار حو الي نصف المبحوثين إلي غياب دور الجمعيات الزر اعية في دعمه وحمايتهم

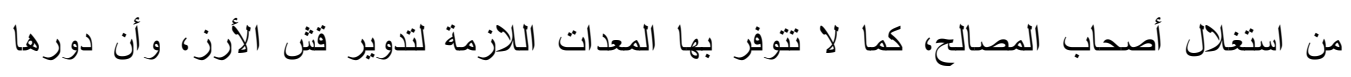

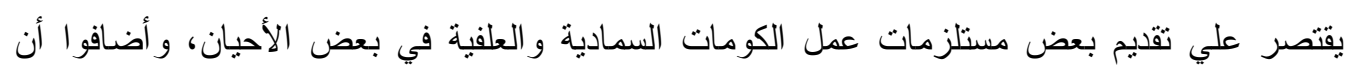


ذلك يعرضهم إلي ضياع فرص الاستفادة من مز ايا تدوير قش الأرز أسوة بكبار الزراع الذين يمتلكون

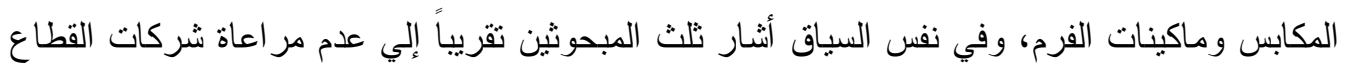

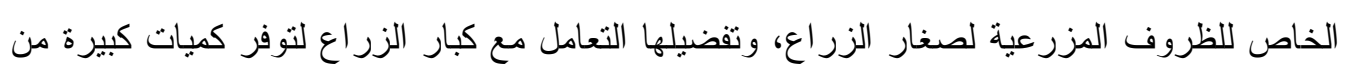

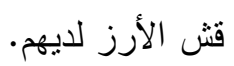
أما فيما يختص بدور وزارة البيئة فقد اتضح أن نسبة كبيرة من المبحوثين من الزراع علي

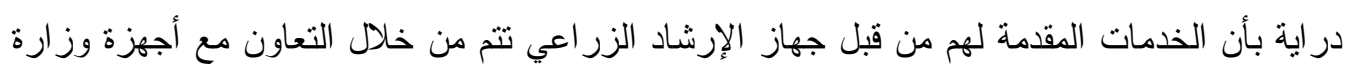

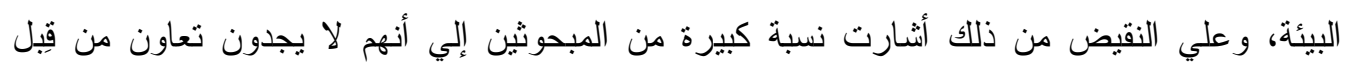

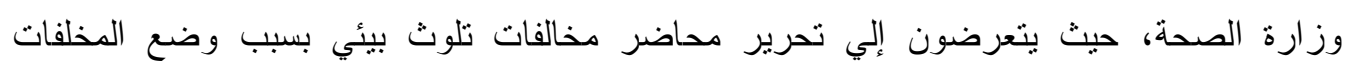
الحيو انبة بالحقل.

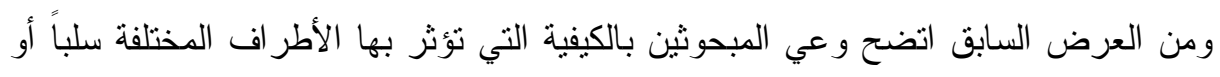

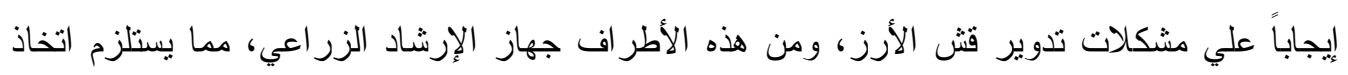

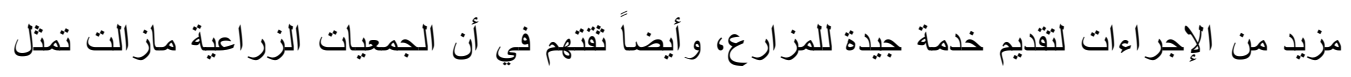

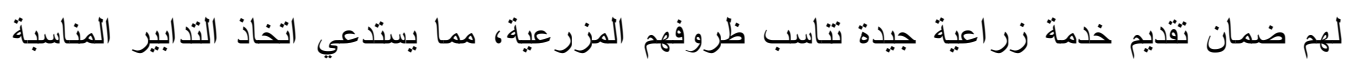

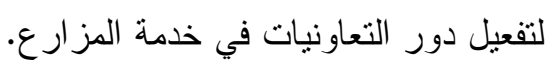

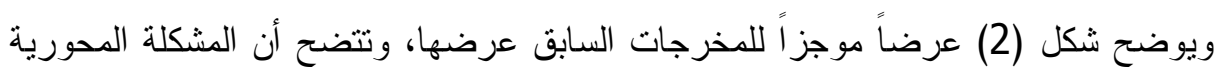

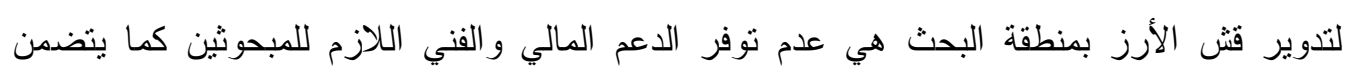

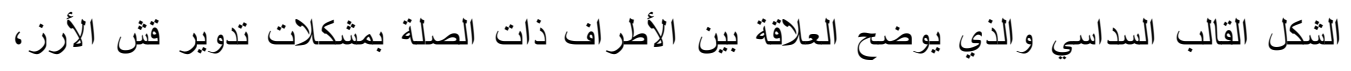

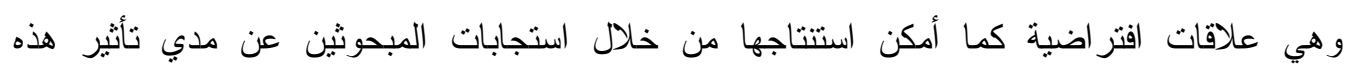
الأطر اف علي حل مشكلات تدوير قش الأرز، وقد يمكن التحقق منها من خلال دراسات أخري تستهدف الكثف عن طبيعة هذه العلاقات. و المز ارع بصفته المتضرر من مشكلات تدوير قش الأرز ، والمستهدف بتتفيذ بأنشطة التدوير

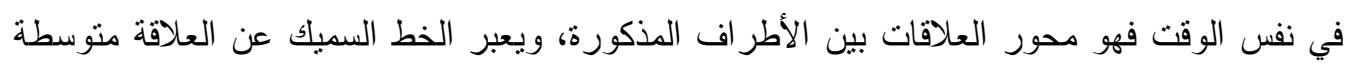
القوة بين جهاز الإرشاد الزر اعي وكل من الجمعيات التعاونية الزراعية، ووز ارة الدولة لفعلة لشئون البيئة، حيث تتحصر العلاقة بينهم في بعض أثكال التعاون في نوفير مستلزمات تتفيذ الكومات السمادية

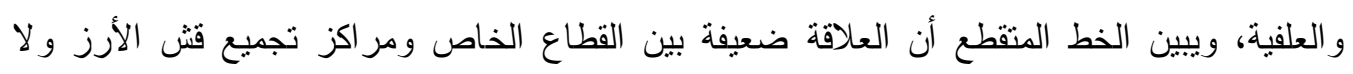

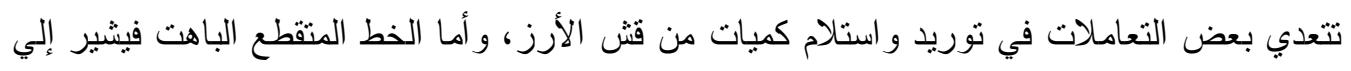

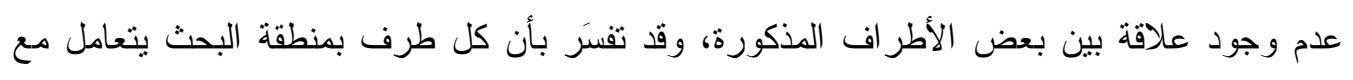
مجال تدوير قش الأرز ومشكلاته بمعزل عن الأطر اف الأخري. 
กัก
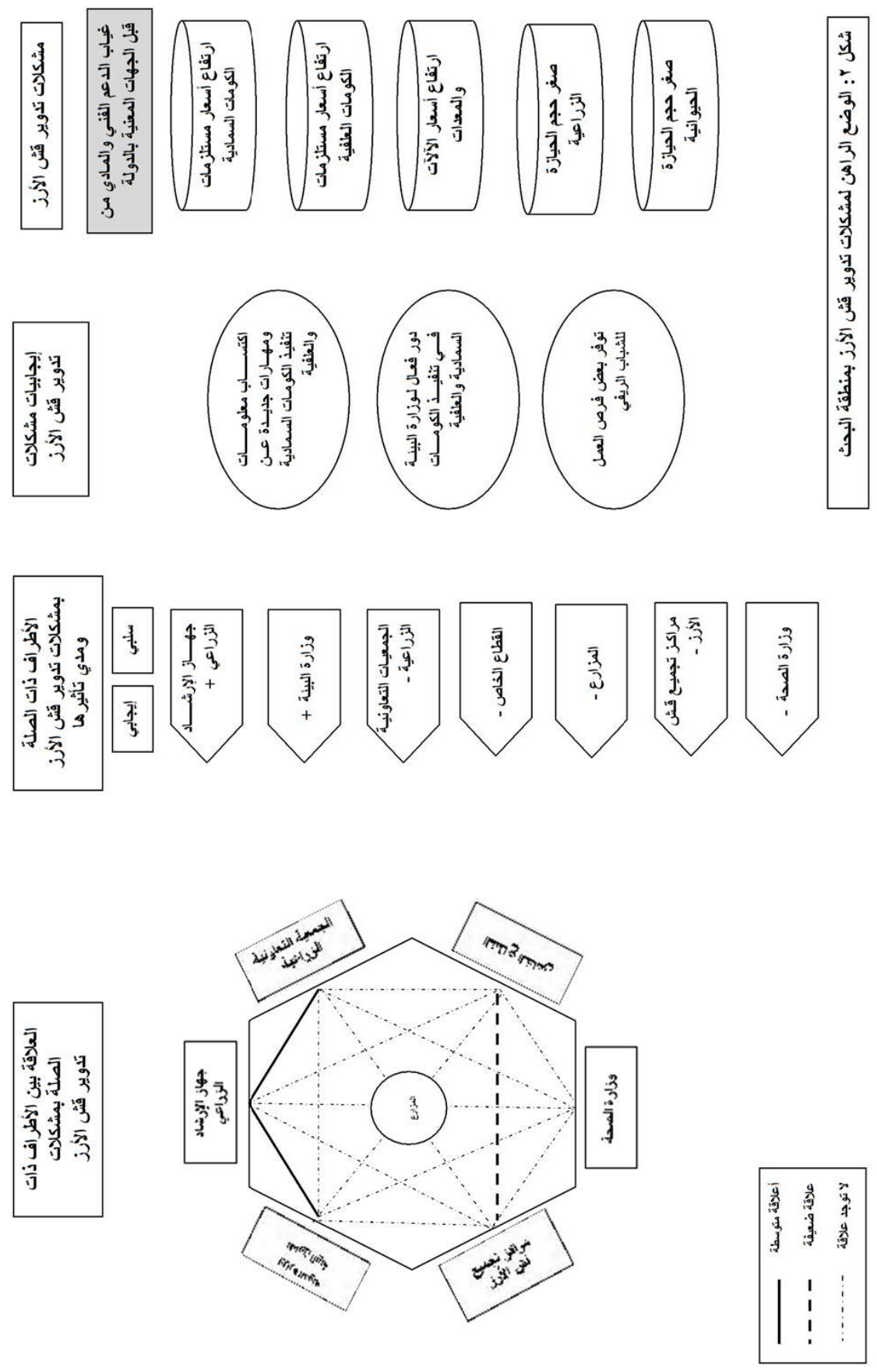
ثالثاً: التعرف علي آراء المسئولين والتنفيذيين من جهاز الإرشاد الزراعي في مشكلات تدوير قش الأرز بمحافظة البحيرة بعد التعرف علي أبعاد مشكلات تدوير قش الأرز من وجهة نظر الزراع المبحوثين من

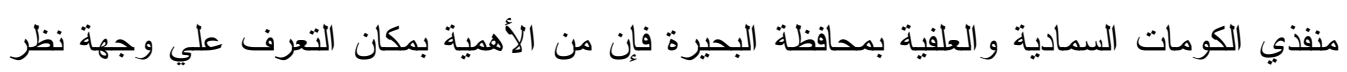

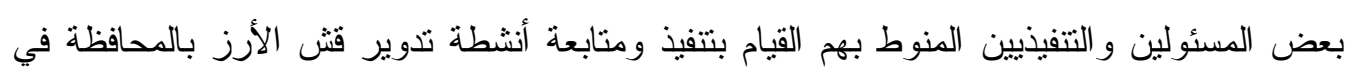

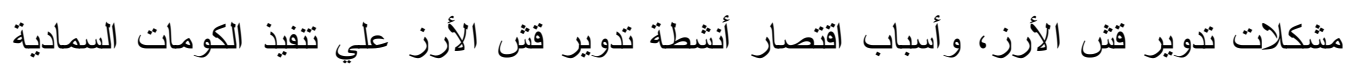

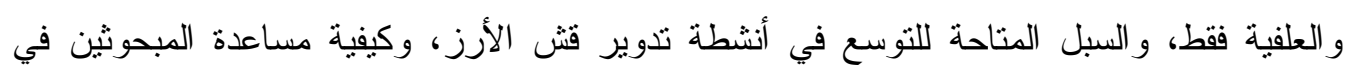

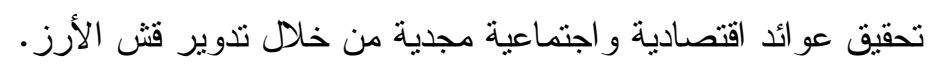

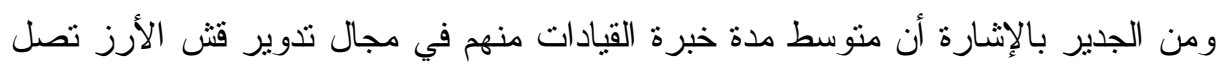

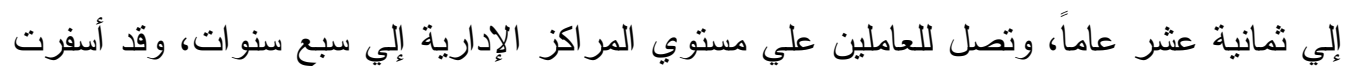

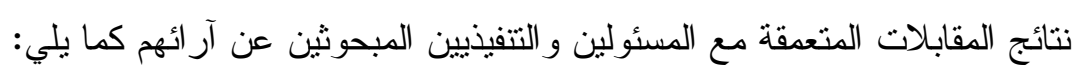
1- مشكلات تدوير قش الأزر بمحافظة البحيرة

أمكن تصنيف المشكلات التي نواجه الزراع عند إجراء تدوير قش لأش الأرز كما ذكرها المبحوثون إلي:

مشكلات تتعلق بالإمكانيات والمستلزمات المطلوبة لتنفيذ الكومات السمادية و العلقية وهي: - قلة عدد ماكينات الفرم لتقطيع قش الأرز ، و المكابس لعمل البالات. - صعوبة توفير مادة Effective Microorganisms) EM-1) المطلوب إضافتها للكومة السمادية. - قلة الأماكن المناسبة لدي الزرفير مادة التخزين قش الأرز .

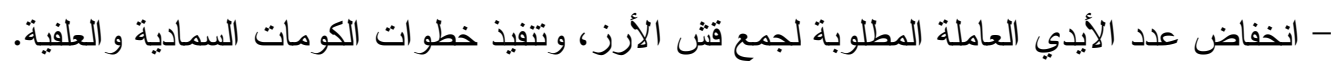
مشكلات تتعلق بالوضع الاقتصادي للزراع وهي:

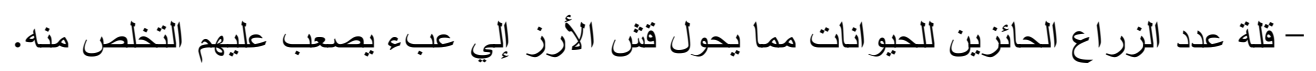

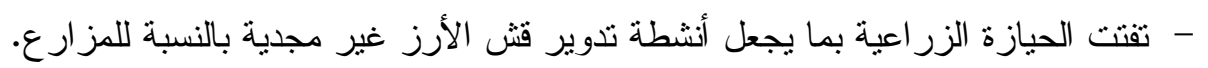
- ارتفاع تكاليف استئجار المعدات المطلوبة لتقليب الكومة السمادية. - انخفاض سعر الطن من فث الأرز عن تكاليف جمعه ونقله. - ارتفاع أسعار العمالة الزر اعية المطلوبة.

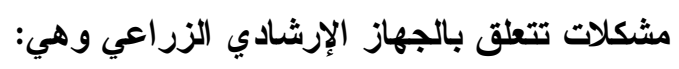

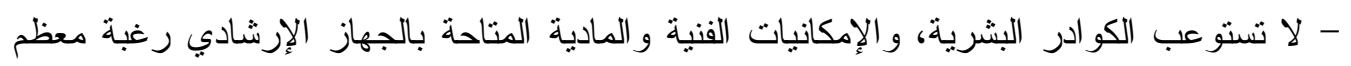
الزراع في التخلص من قش الأرز بأر اضيهم لتجهيز ها لزر اعة المحصول الثنتوي.

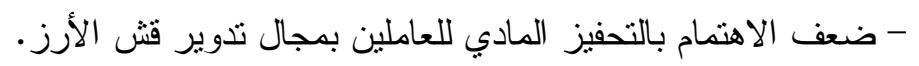

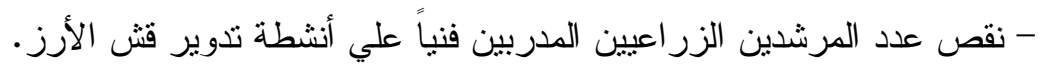

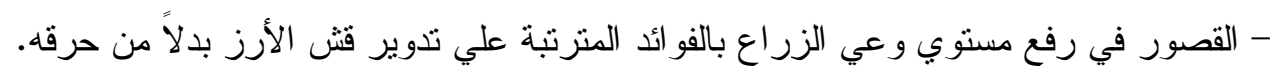

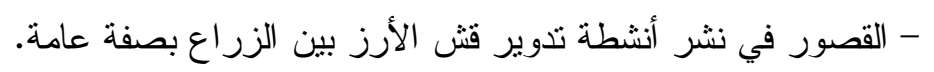




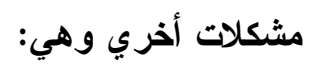

- صعوبة تتفيذ شروط إنشاء مر اكز تجميع قش الأرز .

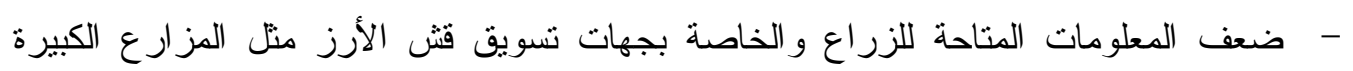
و المصانع.

2- أسباب اقتصار تقنيات تدوير قش الأرز علي تنفيذ الكومات السمادية والكومات العلفية فقط أوضح المبحوثون أن هنالك تقنيات أخري ممكنة، ومربحة للاستفادة من بالات فش الأش الأرز

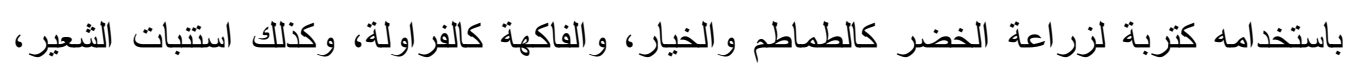
و عيش الغراب إلا أن نركيز تدوير قش الأرز في الكومات السمادية والعلفية فقط قد برجع إلي ما - يتم تتفيذ أنشطة تدوير قش الأرز وفقاً للبرتوكول الموقع بين وزارة الزر اعة ووزارة الدولة لشئون البيئة، و الذي يستهدف تتفيذ الكومات السمادية و العلفية فقط. - تعتبر تقنيات تدوير فش الأرز إلي كومات سمادية وعلفية هي الأقل تكلفة بالنسبة للمز ارع.

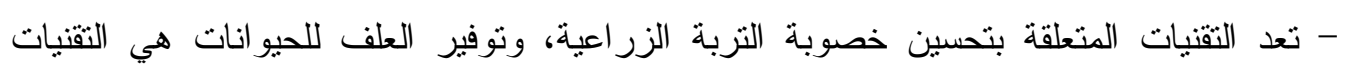

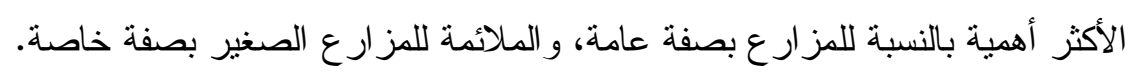

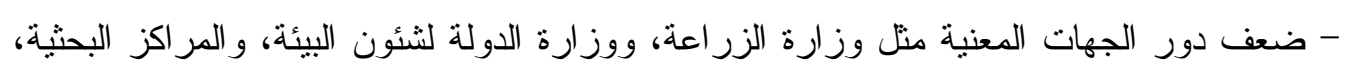

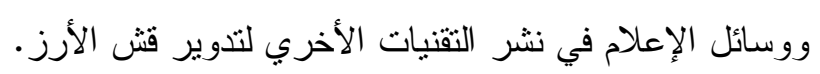
- نقص الآلات أو الماكينات المطلوبة لتنفيذ تقنيات أخري، و وارتفاع أسعار ها. - توفر الدعم الفني و المادي لتتفيذ الكومات السمادية و العلفية فقط. 3- السبل المتاحة للتوسع في أنشطة تدوير قش الأرز ذكر المبحوثون بعض الاقتراحات التي من شأنها أن تساعد في التوسع في تنفيذ أنثطة فئونة

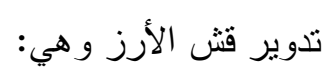

- تعريف الزر اع من خلال الندوات الإرشادية العو ائد الاقتصادية، والاجتماعية، و البيئية الناتجة عن

$$
\text { تذوير فش الأرز ، وتتجيعهم علي تنبي الفكرة. }
$$

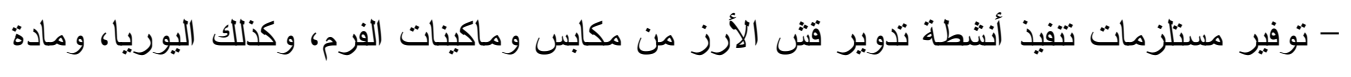
EM-1 علي مستوي مر اكز محافظة البحيرة، وبالجمعيات الزر اعية. - الاهتمام بدعم المرشدين الزر اعيين بالحو افز المناسبة.

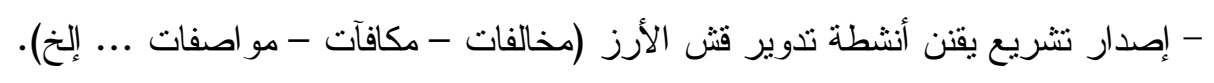
- توفير التدريب الفني لإعداد مرشد زر اعي متخصص في مجال تدوير قش الأرز •

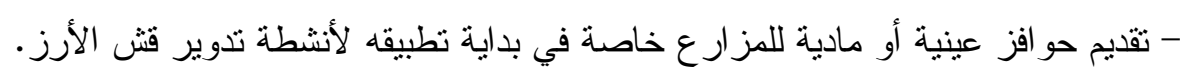

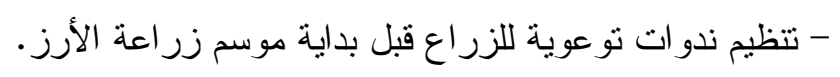

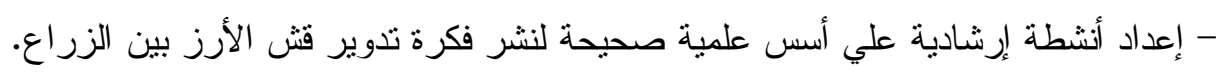




\section{4- عو ائد تنفيذ أنشطة تدوير قش الأرز}

يستطيع المزارع في إطار تدوير قش الأرز تحقيق الكثير من العوائد الاقتصادية

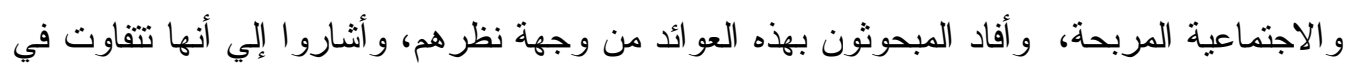

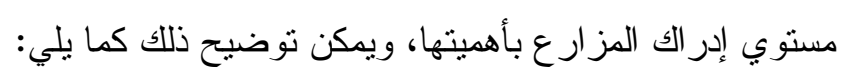

\section{العو ائد الاقتصادية}

تعنبر العوائد الاقتصادية هي الأعلي إدراكاً من قِبل الزراع المبحوثين، و لأنها تتعلق

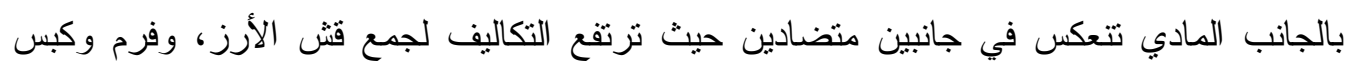

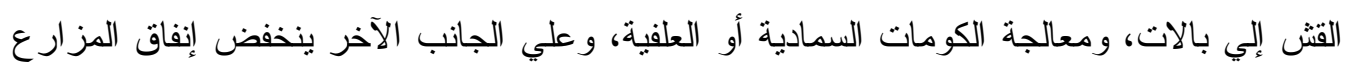

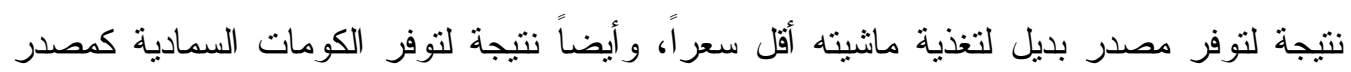
يزيد من خصوبة التربة بديلاً عن إضافة الأسمدة الكيماوية.

\section{العوائد الاجتماعية}

تظهر العوائد الاجتماعية لأنشطة فش الأرز في صورة العمل الجماعي الذي يجمع بين

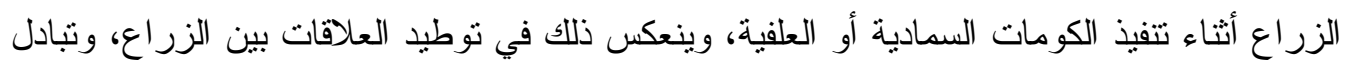

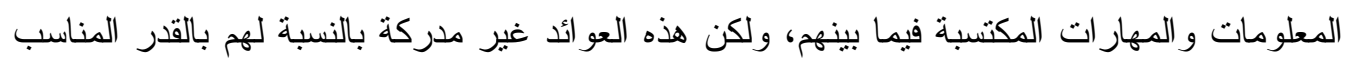

$$
\text { لقيمتها الحقيقية. }
$$

ركز المبحوثون علي أن العو ائد البيئية الناتجة عن النوقف عن حرق قش الأرز تعد من أهم

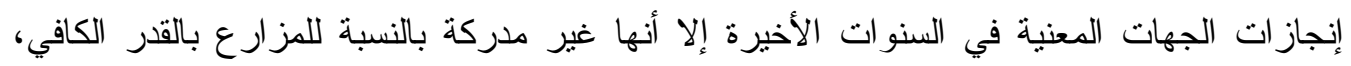

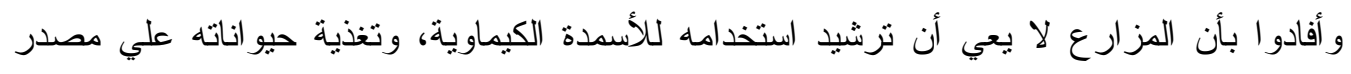
غذائي آمن من أهم العو ائد البيئية أيضاً.

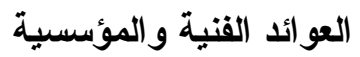

أفاد المبحوثون بأن العو ائد الفنية و المؤسسية ليست محل اهتمام من المز ارع أو العاملين

$$
\text { بالجهات و الهيئات المختلفة. }
$$

ومن العرض السابق اتضح أن استجابات المبحوثين من المسئولين والتتفيذيين اتسقت مع دع دان

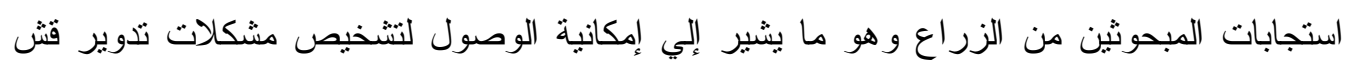

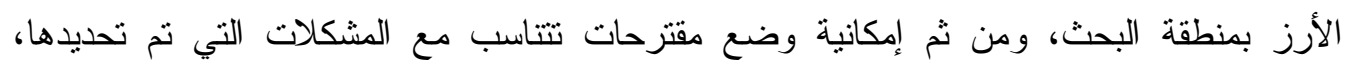
و أسفرت استجابات المبحوثين من المسئولين و التتفيذيين عن الكثير من النقاط و الملاحظات الجديرة

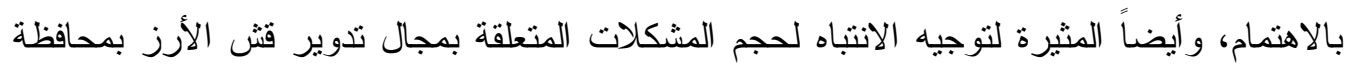
البحيرة والتي يمكن اعتبار ها نقاط انطلاق نحو حل هذه المشكلات أو الحد منها.

\section{الخلاصة}

من النتائج السابقة اتضح أن استخدام مصفوقة الذكاء في تحليل مشكلات تدوير قش الأرز بمنطقة البحث كثف عن بعض العناصر الجديرة بالاهتمام، و علي سبيل المثال أنه بالرغم من معاناة 
المبحوثثن من المشكلات الخاصة بتدوير قش الأرز منذ حوالي 10 سنوات إلا أنها ماز الت في حكم

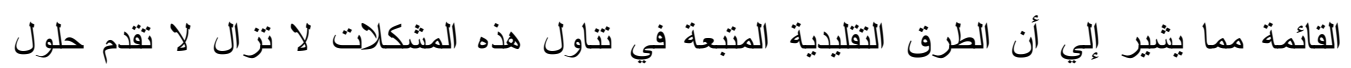
و اقعية أو مقبولة من وجهة نظر الزر اع المبحوثين.

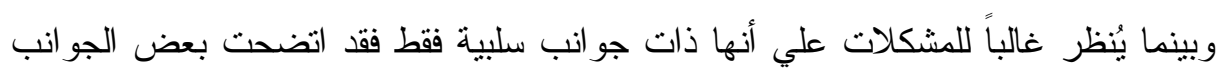
الإيجابية لمشكلات تدوير قش الأرز، و استطاع الزراع المبحوثين أن يعبروا عن بعض الفولئن ائد كنتيجة

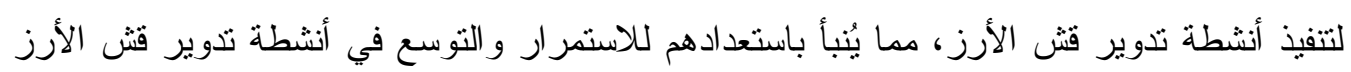
إذا ما ظهرت حلول و اقعية للمشكلات التي يو اجهونها. أما الأطر اف ذوات الصلة بهذه المشكلات فقد نبين معرفة الزراع المبحوثين بها يشكل مناسب سواء كانت جهات أو أفراد من خلال اتصالهم المباشر أو غير المباشر بها، كما تبين أنهم علي وعي كبير بما تمنته هذه الجهات لهم سواء من خلا الدعم والتوعية في نشاطهم المزرعي

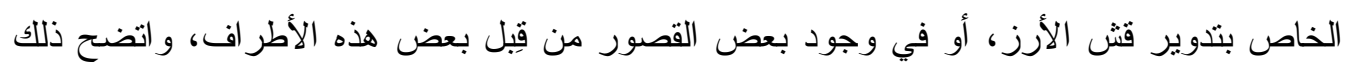

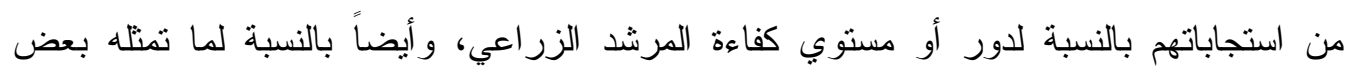

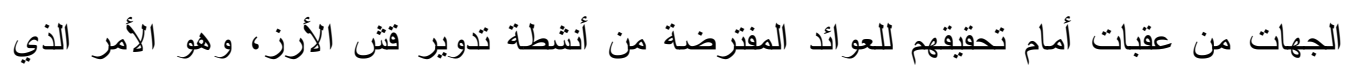

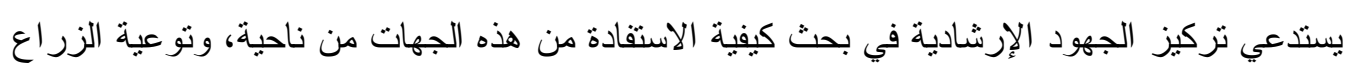

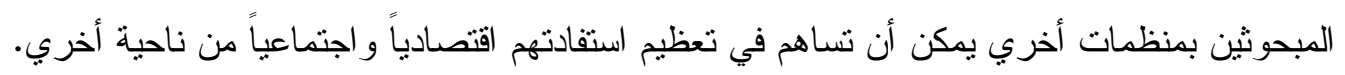

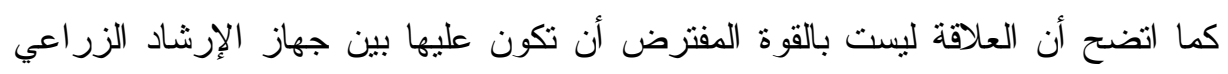

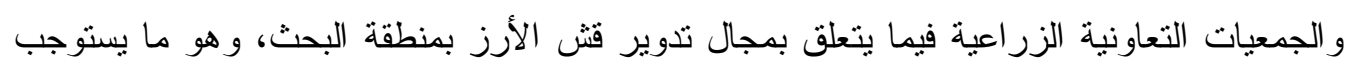

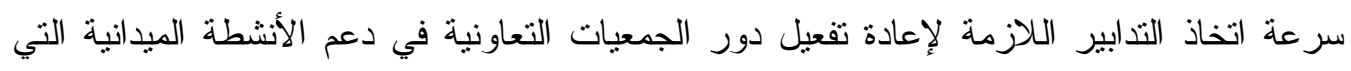

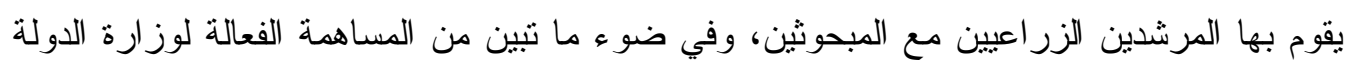

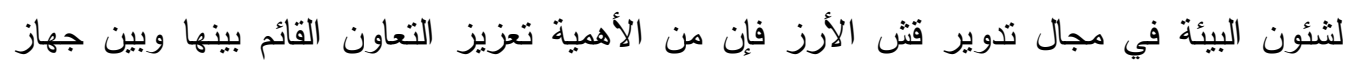

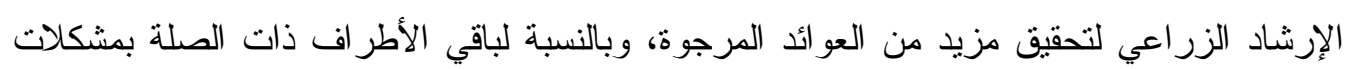

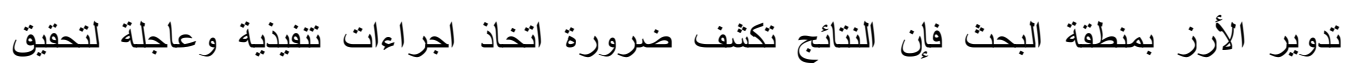

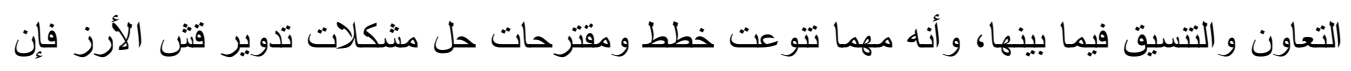

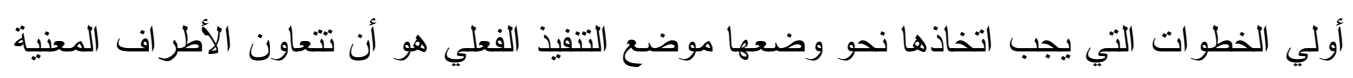
لتتفيذها، و التحقق من نتائج نطبيقها. ويشير الوضع الر اهن لتدوير فش الأرز بمحافظة البحيرة إلي وجود مشكلات متعددة تتعلق

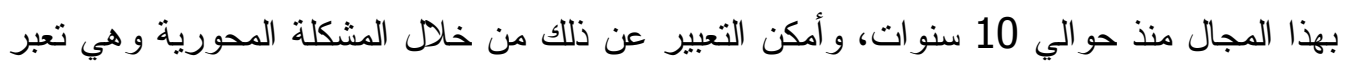

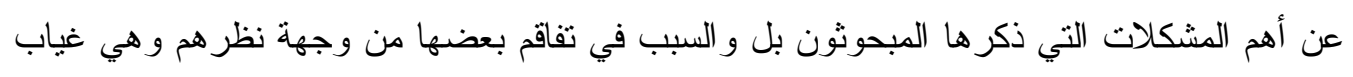
الدعم الفني و المادي اللازم للمز ارع، وتفرع منها سهمين متعرجين سميكين، الأول يشير للمشكلات

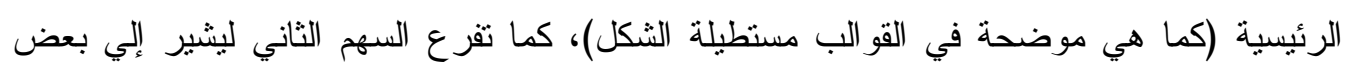

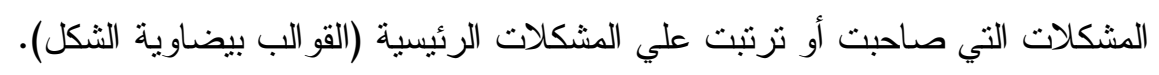

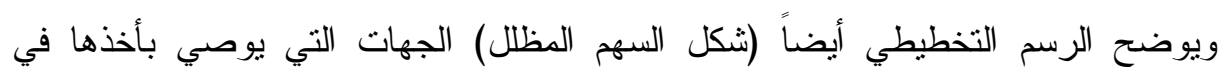
الاعتبار ويمكن أن تساهم في حل أو الحد من بعض هذه المشكلات، ومو اقع تدخلاتها (الأسهم). 
وأخيراً وكما أُثنير سلفاً فإن من الضروري أن ينوفر التعاون و التتسيق بين الجهات المعنية بحل مشكلات تدوير قش الأرز بمنطقة البحث، وموضح بالثكل قوة العلاقة بين المبحوث و الجهات

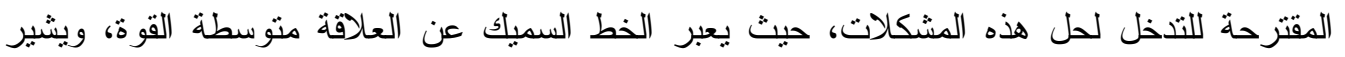

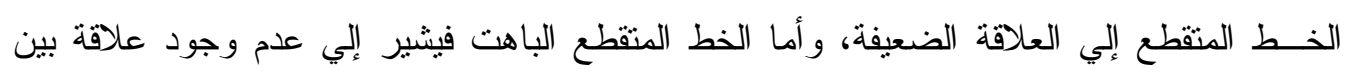

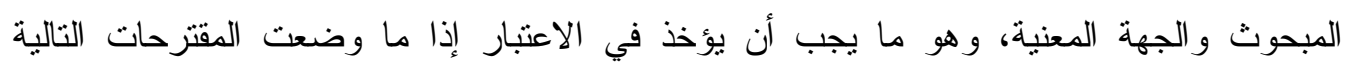
موضع التتفيذ لضمان نجاح تطبيقها، وتحقيق المرجو منها، وفيما يلي إيجاز لهذه المقترحات وفقاً للمشكلات المذكورة:

\section{بعض المقترحات لحل مشكلات تدوير قش الأرز بمحافظة البحيرة}

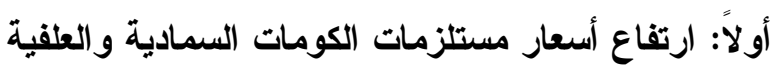

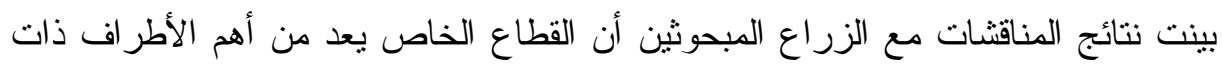

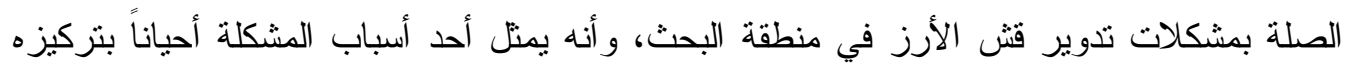

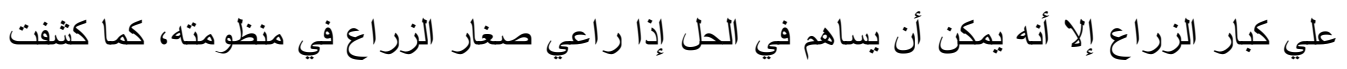

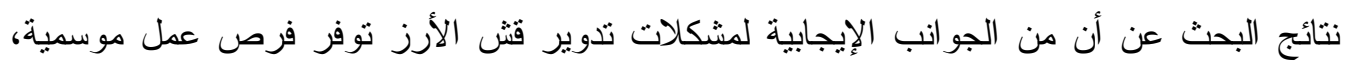

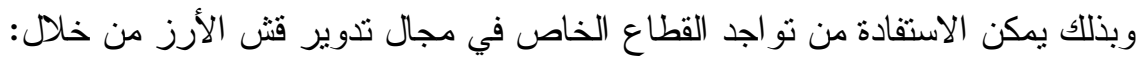

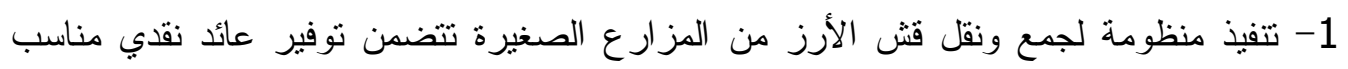

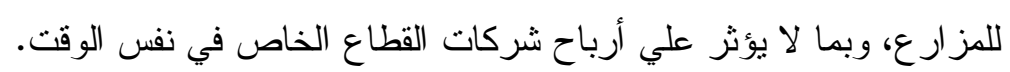
2- إتاحة المعلومات التسويقية الضرورية لصغار الزراع عن كميات قش الأرز المطلوبة، وطريقة الوصول إلي جهات التسويق. 3- نوفير شركات القطاع الخاص لبعض فرص العمل الإضافية لأفر اد أسر صغار الزراع وخاصة

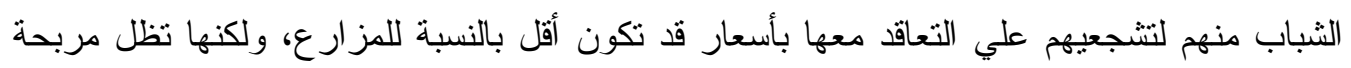
للطرفين. 4- توفير بعض مستلزمات تتفيذ الكومات السمادية و العلفية للزر اع بسعر زهيد نظير نوريدهم لقش

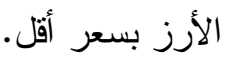
ثانياً: ارتفاع أسعار الماكينات ومكابس الفرم في ضو ء ما أوضحته النتائج من ثقة الزراع في الجمعيات الجيات التعاونية الزر اعية باعتبار ها إحدي الجهات التي يأمل أن تخدمه، وتحميه من استغلال الوسطاء يمكن للمسئولين التقدم بمقترح

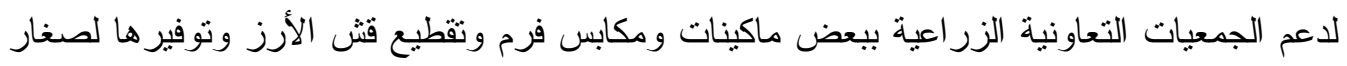

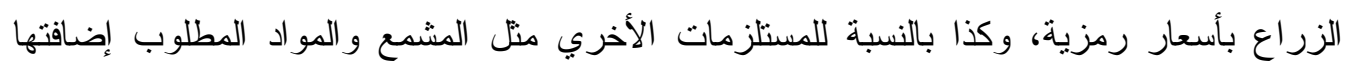
للكومات السمادية و العلفية.

ثالثاً: صغر حجم الحيازة الزراعية والحية والتهانة علي الرغم من أنه بوجه عام لكثير من المنظمات غير الحكومية عدد من الإنجاز ات في

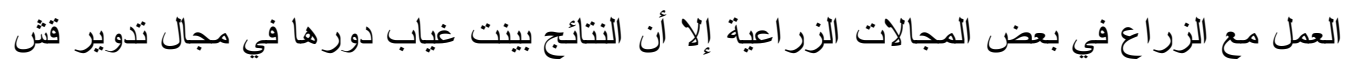

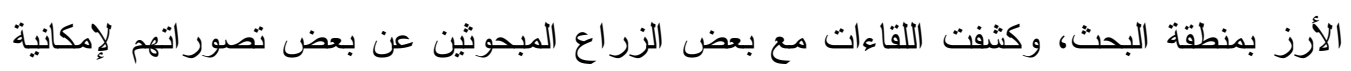


مساهمة المنظمات غير الحكومية في حل مشكلاتهم في مجال تدوير قش الأرز، منل تتفيذ بعض الاض أندات

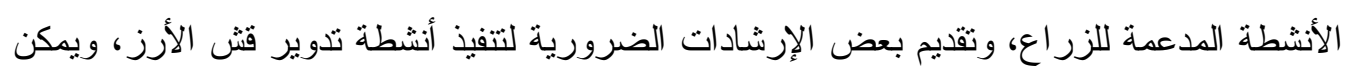

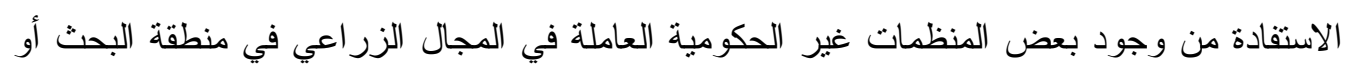
المناطق المجاورة في حل مشكلات تدوير قش الأرز من خلال: 1- حث صغار الزراع علي العمل في مجموعات لحل مشكلة صغر حجم الحيازة الزر اعية و الحيو انية لايهم، علي أن تعمل المنظمات غير الحكومية كوسطاء بين هذه المجموعات وشركات

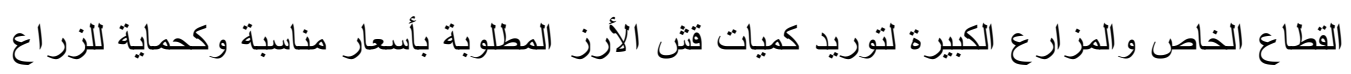
من استغلالكم. - من 2- التعاون مع أحد الجهات التتموية المعنية بالمجال الزر اعي لتتفيذ برامج تدريبية للزر اع المبحوثين

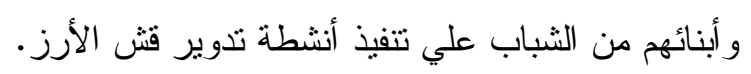
3- تقديم تدريب إضافي للزراع علي الطرق الصحيحة لكيفية تتفيذ بعض الندوات وات واللقاءات

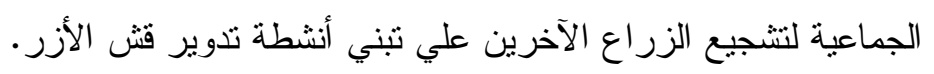

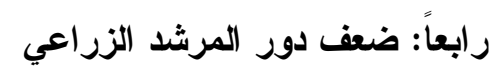

يظل المرشد الزراعي هو الثخص المنوط به توعية ومساعدة المزارع علي لتئ اتخاذ القرارات المناسبة لظروفه المزرعية، وبالرغم من وجود الكثير من المشكلات التي تعوق المرشد الزراعي عن أداء عمله في مجال تدوير فش الأرز علي النحو المطلوب ويمكن العمل علي تعزيز دور المرشد الزر اعي في هذا المجال من خلال: 1- تعاون الجمعيات التعاونية الزراعية مع المرشدين الزراعين الزين في تتظيم اللقاءات الجماعية مع العي الزراع لتنفيذ الكومات السمادية والعلفية، وأن تكون هناك متابعة من المسئول بالجمعية لنقل أي لتئي

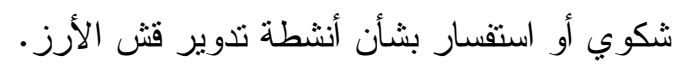

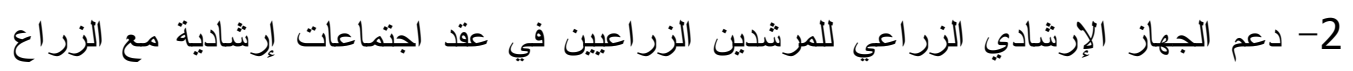

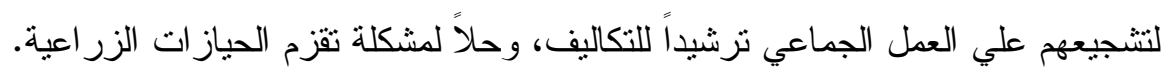

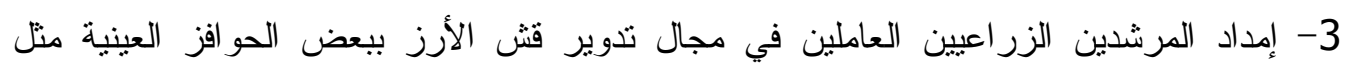

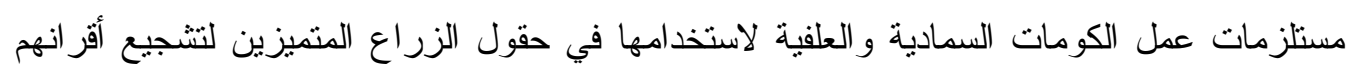
علي تتفيذ الفكرة. خامساً: النقص في توافر المرشد الزراعي المؤهل

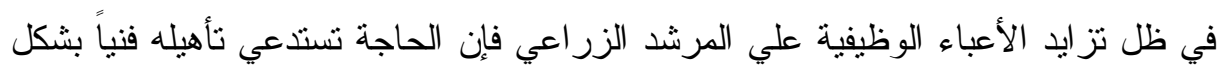

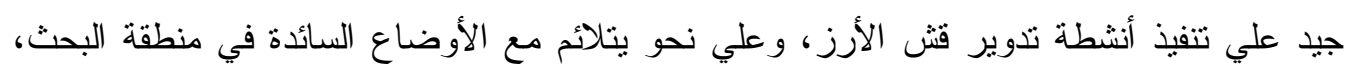

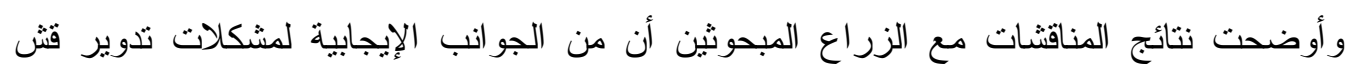

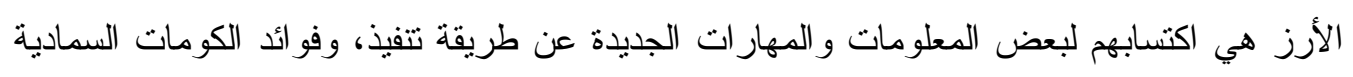

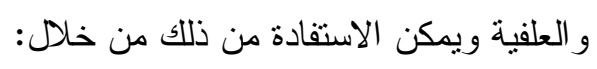

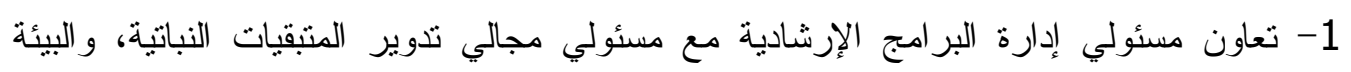

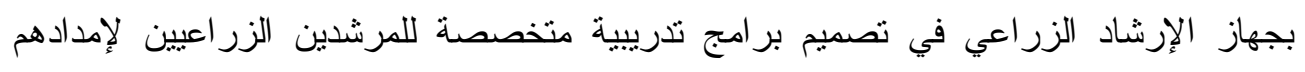


بالمعلومات والمهارات الفنية المتعلقة بالأنشطة المختلفة لتدوير قش الأرز، ولتأهليهم بشكل يتتاسب مع المهام المتوقعة منهم في هذا المجال.

2- تركيز جهاز الإرشاد الزر اعي علي تدريب المرشدين الزر اعيين علي مهارات الإقناع، و أساليب

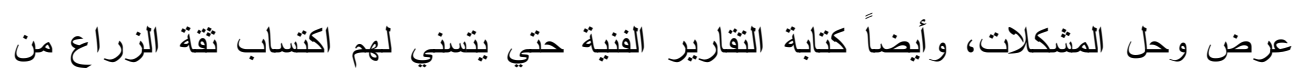

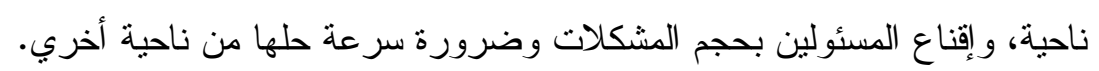

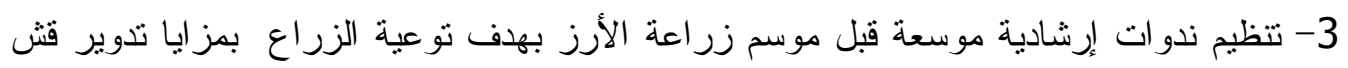

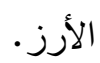

4- الانتظام في مو اعيد تتفيذ الكومات السمادية و العلفية ويسبقها الدعاية اللازمة في حقول الزراع.

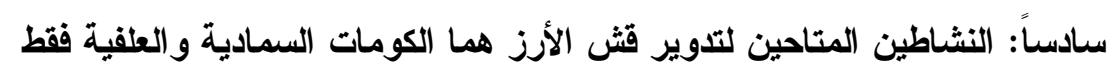

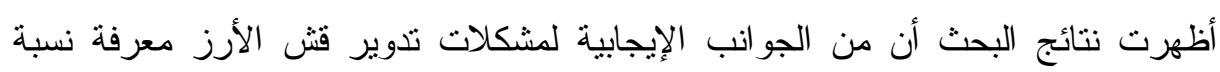

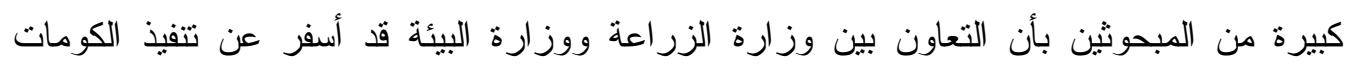

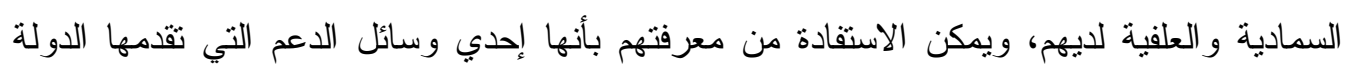

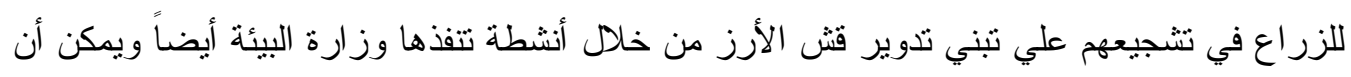

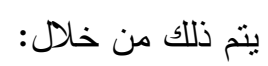
1- التعاون مع جهاز الإرشاد الزر اعي بالمحافظة في إعداد مرشدين زر اعيين مدربين علي الأنشطة

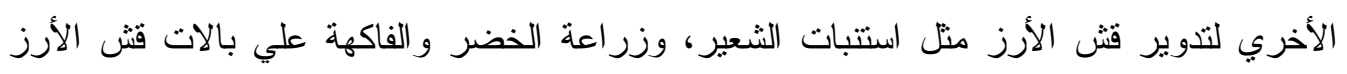
وغير ها من الأنشطة المربحة اقتصادياً.

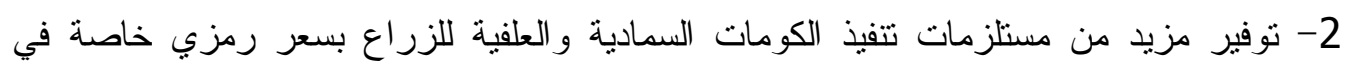

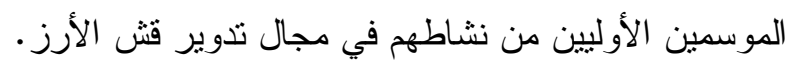

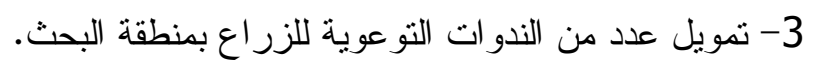


$\stackrel{n}{0}$

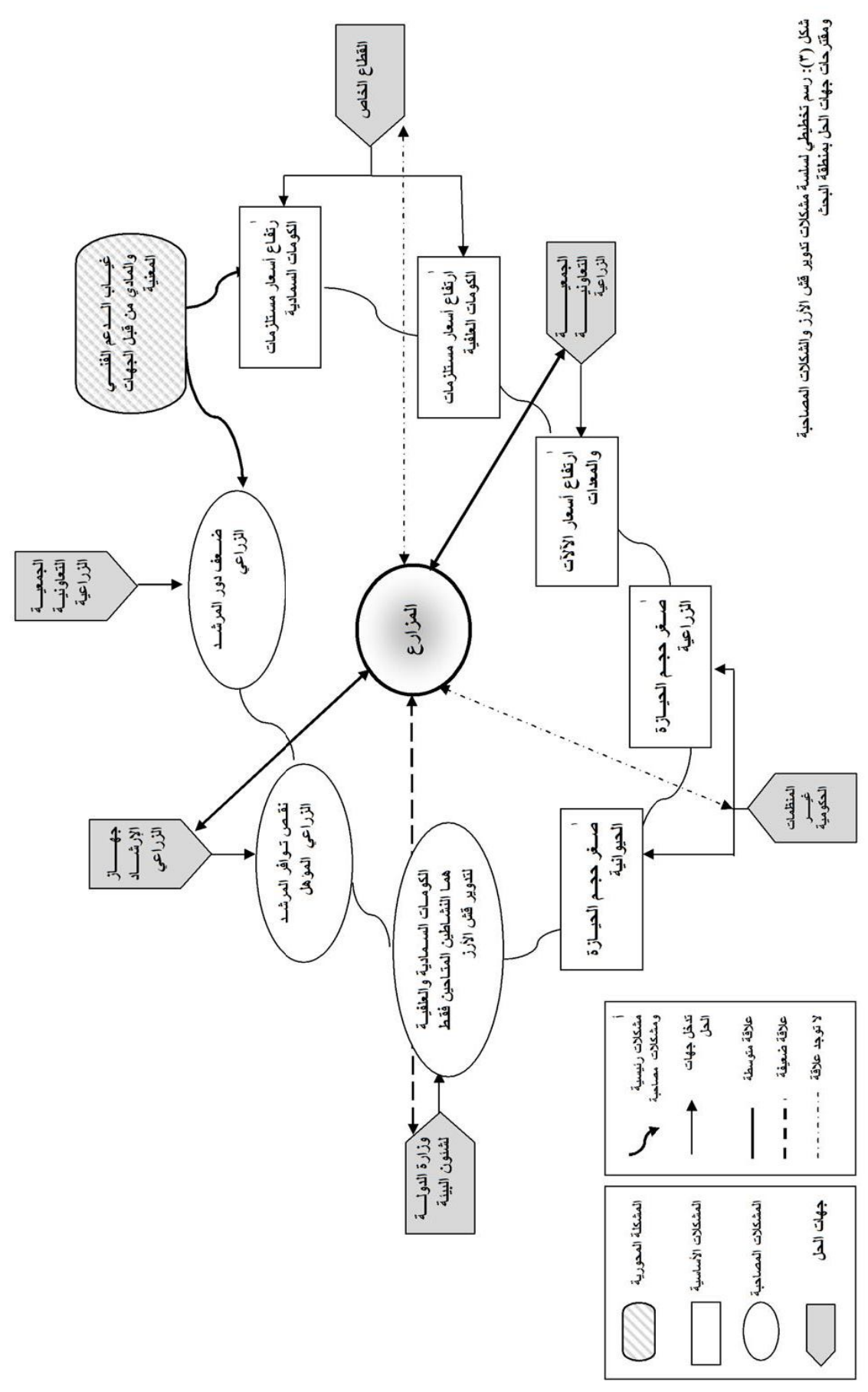




$$
\begin{aligned}
& \text { المر اجــ } \\
& \text { 1- إدارة الإرشاد الزر اعي (2017)، مديرية الزر اعة بمحافظة البحيرة، بيانات غير منشورة. }
\end{aligned}
$$

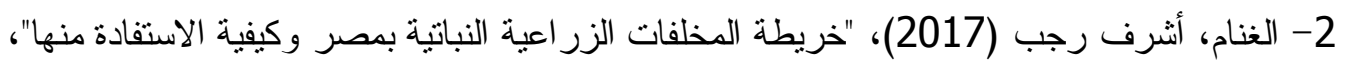

$$
\begin{aligned}
& \text { وز ارة الدولة لشئون البيئة، بيانات غير منشورة. }
\end{aligned}
$$

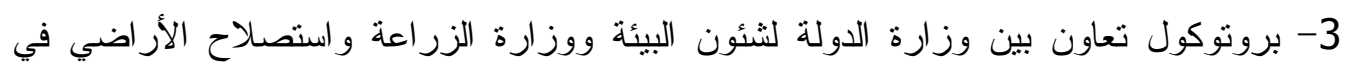

$$
\begin{aligned}
& \text { مجال تدوير قش الأرز (2017)، بيانات غير منشورة }
\end{aligned}
$$

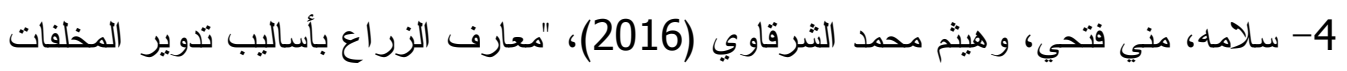

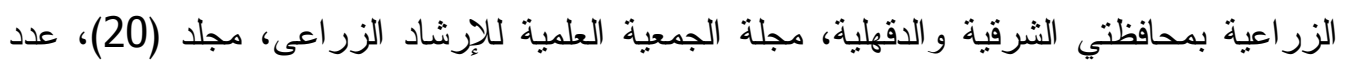

$$
\begin{aligned}
& \text { 5- صوان، أميمة محمد وآخرون (2010)، "دليل تدوير المخلفات الزر اعية"، جهاز شئون البيئة، } \\
& \text { وز ارة الدولة لشئون البيئة. }
\end{aligned}
$$

Available at: http://www.eeaa.gov.eg/portals/0/eeaaReports/AgrWasteRecycleGuide/A.W.R.G\%202010.pdf Accessed 6-2-2016

$$
\begin{aligned}
& \text { 6- عبد الله، حمزة حامد، ومؤمن السيد نعيم، وكرم يوسف عازر (2015)، "معارف الزر اع بتدوير }
\end{aligned}
$$

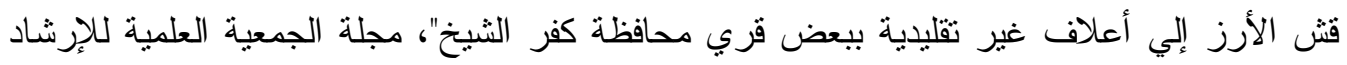

$$
\begin{aligned}
& \text { الزر اعى، مجلد (19)، عدد (3). } \\
& \text { 7- عز ام، عبد الثافي أحمد، وعادل عبد السميع علي، ومدحت عزت عبد الوداب الوهاب (2011)، " تبني } \\
& \text { تحويل قش الأرز إلي أعلاف غير تقليدية لدي زراع الأرز بإحدي قري محافظة الدقهلية، المجلة }
\end{aligned}
$$

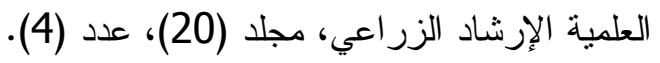

$$
\begin{aligned}
& 8 \text { - قطب، إلهام أحمد أحمد (2004)، "محددات إعادة تدوير المخلفات الزر اعية بمحافظتى الفيوم }
\end{aligned}
$$

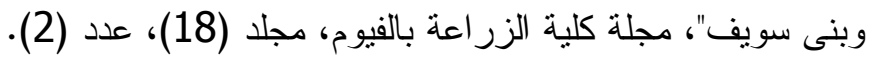

9- Ahmed T., Bashir Ahmad and Waseem Ahmad (2015), "Why do farmers burn rice residue? Examining farmers", choices in Punjab, Pakistan", Journal of Land Use Policy, Volume 47, September.

Available at: https://www.sciencedirect.com/science/article/pii/S0264837715001441

Accessed 1-3-2017

10- Hofstrand D.,(2009), "Crop Residue - A Valuable Resource", Agricultural Marketing Resource Center, Iowa State University U.S.

Available at: https://www.agmrc.org/renewable-energy/ethanol/crop-residue-avaluable-resource/Accessed 8-2-2017

11- Kokotovich, V. (2008), "Problem analysis and thinking tools: an empirical study of non-hierarchical mind mapping", Faculty of Design, University of Technology, Australia, Journal of Design Studies, Volume 29, Issue 1.

Available at: https://sci-hub.tw/https://doi.org/10.1016/j.destud.2007.09.001

Accessed 11-3-2018 
12- Loban, S., et.al (2018), "Burning issues of paddy residue management in northwest states of India", Journal of Renewable and Sustainable Energy Reviews, Volume 81, Part 1.

Available at: https://www.sciencedirect.com/science/article/pii/S1364032117311966

Accessed 5-4-2018

13- Sicinki, A. (2014), About IQ Matrix, "Mind Maps, Self-Growth and Visual Thinking". Available at: https://iqmatrix.com/about/

Accessed 10-12-2016

14- Sicinki, A. (With no date), IQ Matrix, "The complete guide on how to mind map for beginners" Available at: https://blog.iamatrix.com/how-to-mind-map

Accessed 10-12-2016

15- Sicinki, A. (With no date), IQ Matrix, "A beginner's guide for becoming a better problem solver".

Available at: https://blog.iqmatrix.com/better-problem-solver

Accessed 10-12-2016

16- Sicinki, A. (With no date), IQ Matrix, "Creative Problem Solving Part 1: Defining Your Problem.

Available at: https://blog.iqmatrix.com/defining-problem

Accessed 12-12-2016

17- Sicinki, A. (With no date), IQ Matrix, Creative Problem Solving Part 2: Investigating Your Problem.

Available at: https://blog.iqmatrix.com/investigating-problem

Accessed 12-12-2016

18- Sicinki, A. (With no date), IQ Matrix, "Creative Problem Solving Part 3: Re-Imagine Your Idea.

Available at: https://blog.iqmatrix.com/re-imagine-idea

Accessed 12-12-2016

19- Sicinki, A. (With no date), IQ Matrix, "Creative Problem Solving Part 4: Engineer Plan of Action. Available at: https://blog.iqmatrix.com/engineering-plan

Accessed 12-12-2016

20- Sicinki, A. (With no date), IQ Matrix, "Creative Problem Solving Part 5: Execute and Master your_problem.

Available at: https://blog.iqmatrix.com/execute and master

Accessed 12-12-2016

21 - Smith, J., G. et.al (2016), " Assessing Social Learning Outcomes Through Participatory Mind Mapping", Journal of Extension, Volume 54, Number 1, February.

Available at: https://www.joe.org/joe/2016february/tt3.php

Accessed 14-2-2016 
